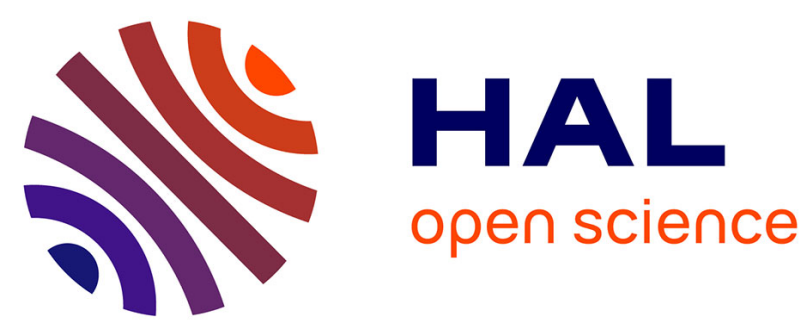

\title{
Acoustic distribution of discriminated micronektonic organisms from a bi-frequency processing: the case study of eastern Kerguelen oceanic waters
}

Nolwenn Béhagle, Cédric Cotté, Anne Lebourges-Dhaussy, Gildas Roudaut, Guy Duhamel, Patrice Brehmer, Erwan Josse, Yves Cherel

\section{To cite this version:}

Nolwenn Béhagle, Cédric Cotté, Anne Lebourges-Dhaussy, Gildas Roudaut, Guy Duhamel, et al.. Acoustic distribution of discriminated micronektonic organisms from a bi-frequency processing: the case study of eastern Kerguelen oceanic waters. Progress in Oceanography, 2017, 156, pp.276-289. 10.1016/j.pocean.2017.06.004 . hal-01552638

\section{HAL Id: hal-01552638 \\ https://hal.science/hal-01552638}

Submitted on 6 Jul 2017

HAL is a multi-disciplinary open access archive for the deposit and dissemination of scientific research documents, whether they are published or not. The documents may come from teaching and research institutions in France or abroad, or from public or private research centers.
L'archive ouverte pluridisciplinaire HAL, est destinée au dépôt et à la diffusion de documents scientifiques de niveau recherche, publiés ou non, émanant des établissements d'enseignement et de recherche français ou étrangers, des laboratoires publics ou privés. 
1 Acoustic distribution of discriminated micronektonic organisms from a bi2 frequency processing: the case study of eastern Kerguelen oceanic waters 3

4 Nolwenn Béhagle ${ }^{\mathrm{a}, b^{*}}$, Cédric Cottéc , Anne Lebourges-Dhaussy ${ }^{\mathrm{a}}$, Gildas Roudaut ${ }^{\mathrm{a}}$, Guy 5 Duhamel $^{\mathrm{d}}$, Patrice Brehmer ${ }^{\mathrm{e}}$, Erwan Josse ${ }^{\mathrm{a}}$, Yves Cherel ${ }^{\mathrm{f}}$

6

7 a IRD, UMR LEMAR 6539 (CNRS-IRD-IFREMER-UBO), BP70, 29280 Plouzané, France

$8 \quad{ }^{\mathrm{b}}$ CNRS, UMR LOCEAN 7159 (CNRS-IRD-MNHN-UPMC), 4 place Jussieu, 75005 Paris,

9 France

10 'MNHN, UMR LOCEAN 7159 (CNRS-IRD-MNHN-UPMC), 4 place Jussieu, 75005 Paris,

11 France

$12{ }^{d} M N H N$, UMR BOREA 7208(MNHN- CNRS-UPMC-IRD-UCBN-UAG), 43 rue Cuvier, CP

13 26,75231 Paris Cedex 05, France

$14{ }^{e}$ IRD, UMR 195 Lemar, ISRA-CRODT, Pole de Recherche de Hann, BP221, Dakar, Sénégal

$15{ }^{\mathrm{f}}$ CNRS, UMR CEBC 7372 (CNRS-Université de La Rochelle), 79360 Villiers-en-Bois, France

16

$17 \quad{ }^{*}$ Corresponding author. E-mail address: nolwenn.behagle@gmail.com 


\section{Abstract}

Despite its ecological importance, micronekton remains one of the least investigated components of the open-ocean ecosystems. Our main goal was to characterize micronektonic organisms using bi-frequency acoustic data (38 and $120 \mathrm{kHz}$ ) by calibrating an algorithm tool that discriminates groups of scatterers in the top $300 \mathrm{~m}$ of the productive oceanic zone east of Kerguelen Islands (Indian sector of the Southern Ocean). The bi-frequency algorithm was calibrated from acoustic properties of mono-specific biological samples collected with trawls, thus allowing to discriminate three acoustic groups of micronekton: $(i)$ "gas-bearing" $\left(\Delta S_{\mathrm{v}, 120-}\right.$ $\left.{ }_{38}<-1 \mathrm{~dB}\right)$, (ii) "fluid-like" $\left(\Delta S_{\mathrm{v}, 120-38}>2 \mathrm{~dB}\right)$, and (iii) "undetermined" scatterers $\left(-1<\Delta S_{\mathrm{v}, 120-}\right.$ $38<2 \mathrm{~dB}$ ). The three groups likely correspond biologically to gas-filled swimbladder fish (myctophids), crustaceans (euphausiids and hyperiid amphipods), and other marine organisms potentially present in these waters and containing either lipid-filled or no inclusion (e.g. other myctophids), respectively. The Nautical Area Scattering Coefficient (NASC) was used (echointegration cells of $10 \mathrm{~m}$ long and $1 \mathrm{~m}$ deep) between 30 and $300 \mathrm{~m}$ depth as a proxy of relative biomass of acoustic targets. The distribution of NASC values showed a complex pattern according to: $(i)$ the three acoustically-defined groups, (ii) the type of structures (patch $v s$. layers) and (iii) the timing of the day (day/night cycle). NASC values were higher at night than during the day. A large proportion of scatterers occurred in layers while patches, that mainly encompass gas-bearing organisms, are especially observed during daytime. This method provided an essential descriptive baseline of the spatial distribution of micronekton and a relevant approach to $(i)$ link micronektonic group to physical parameters to define their habitats, (ii) investigate trophic interactions by combining active acoustic and top predator satellite tracking, and (iii) study the functioning of the pelagic ecosystems at various spatiotemporal scales. 
44 Keywords: Euphausiid, Kerguelen, Myctophid, Southern Ocean, Acoustics. 


\section{Introduction}

Micronektonic organisms ( 1-20 cm in length; Kloser et al., 2009) constitute one of the most noticeable and ecologically important components of the open ocean. They amount to a substantial biomass (e.g. estimated at $>10000$ million metric tons of mesopelagic fish in oceanic waters worldwide and $~ 380$ million metric tons of Antarctic krill in the Southern Ocean; Atkinson et al., 2009; Irigoien et al., 2014) with high nutritional value (Shaviklo and Rafipour, 2013; Koizumi et al., 2014) leading to increasing commercial interest (Pauly et al., 1998). In oceanic waters, micronekton contribute to the export of carbon from the surface to deeper layers (the biological pump) through extensive daily vertical mesopelagic migrations to feed on near-surface organisms at night (Bianchi et al., 2013). They play a prominent role in oceanic food webs by linking primary consumers to higher predators, including commercially targeted fish species and oceanic squids, together with charismatic species, such as marine mammals and seabirds (Rodhouse and Nigmatullin, 1996; Robertson and Chivers, 1997; Potier et al. 2007; Spear et al. 2007). Despite their ecological importance, micronekton remain one of the least investigated components of the marine ecosystems, with major gaps in our knowledge of their biology, ecology, and major uncertainties about their global biomass (Handegard et al., 2013; Irigoien et al., 2014).

Acoustic methods have been used in fishery operations and research since 1935 (Sund, 1935). Stock assessment drove a continuous improvement of the methods in order to better investigate the distribution and abundance of targeted marine organisms (Simmonds and MacLennan, 2005). Beyond stock assessment, acoustics now extends to whole marine ecosystems, being the best available tool allowing simultaneous collection of qualitative and quantitative data on their biotic and even abiotic components (Bertrand et al., 2013). A major limitation of acoustics is the lack of accurate taxonomic information about the ensonified 
organisms. Hence, acoustic analytical tools to determine characteristics of biological backscatters were developed by comparing and quantifying the difference of mean volume backscattering strength between different frequencies. The rationale is that the acoustic properties of individual species are known to vary with the operating frequencies of the echo sounder. For example, both experimental and theoretical studies showed large variations in the average echo energy per unit biomass due to animals from "fluid-like" to "elastic shelled" organisms (Stanton et al., 1994, 1998a, 1998b). This approach has been used since the late 1970s to identify and quantify zooplanktonic scatterers (Greenlaw, 1977; Holliday and Pieper, 1980; Madureira et al., 1993a,b). Less has been done to characterize micronektonic organisms from the open sea, where micronekton are diverse and include small pelagic fishes, cephalopods, large crustaceans and gelatinous animals. A recent biomass estimate of midwater fish was based on the $38 \mathrm{kHz}$ frequency alone (Irigoien et al., 2014). Furthermore, the difference of mean volume backscattering strength between two frequencies (38 and $120 \mathrm{kHz}$ ) was used to differentiate "fish", "macrozooplankton" and "zooplankton" scatterers (Fielding et al., 2012; Bedford et al., 2015).

In the Southern Ocean (water masses south of the Subtropical Front), the importance of micronekton is illustrated by the considerable populations of subantarctic seabirds and pinnipeds that primarily prey on schooling myctophids, swarming euphausiids and hyperiid amphipods (Cooper and Brown, 1990; Woehler and Green, 1992; Guinet et al., 1996; Bocher et al., 2001). However, to our knowledge, acoustic investigation of mid-water organisms in lower latitudes of the Southern Ocean is limited to a few surveys (Miller, 1982; Perissinotto and McQuaid 1992; Pakhomov and Froneman, 1999), and only three recent studies discriminated acoustic groups by their bi-frequency characteristics (Fielding et al., 2012; Saunders et al., 2013; Bedford et al., 2015). 
The main goal of the present work was to use bi-frequency acoustic data (38 and 120

$95 \mathrm{kHz}$ ) combined with net sampling to calibrate an algorithm tool that discriminates groups of scatterers in an acoustically poorly-explored area. The targeted region was the productive oceanic zone off south-eastern Kerguelen Islands, because: $(i)$ several significant populations of predators are known to feed on micronektonic organisms in the area during the summer months, namely Antarctic fur seals and king penguins on mesopelagic fishes (mainly

100 myctophids) and macaroni penguins on euphausiids and hyperiids (Bost et al., 2002;

101 Charrassin et al., 2004; Lea et al., 2002; C.A. Bost and Y. Cherel, unpublished data); and (ii)

102 myctophid fishes and euphausiids were already successfully collected in the area (Duhamel et

103 al., 2000, 2005; authors' unpublished data). The rationale was that different groups of 104 micronektonic organisms (large crustaceans and mid-water fish) should be abundant in the 105 targeted area and that the bi-frequency acoustic data should allow investigating their 106 horizontal and vertical abundance patterns according to the type of structures (patches and 107 layers). 


\section{Materials and methods}

109

The oceanographic cruise (MD197/MYCTO) was carried out during the austral

111 summer 2013-2014 on board the R/V Marion Dufresne II. The overall dataset was based on

$1121,320 \mathrm{~km}$ of acoustic data in oceanic waters off Kerguelen Islands during 14 consecutive days

113 of recording.

114

115

\subsection{Acoustic sampling}

116

In situ acoustic data were recorded day and night during the period 23 January-5

117 February 2014. Measurements were made when cruising at a speed of 8 knots, using a Simrad

118 EK60 split-beam echo sounder operating simultaneously at 38 and $120 \mathrm{kHz}$. The transducers

119 were hull-mounted at a depth of $6 \mathrm{~m}$ below the water surface. An offset of $30 \mathrm{~m}$ below the

120 surface was applied to account for: $(i)$ the depth of the transducers, (ii) the acoustic Fresnel

121 zone, and (iii) the acoustic interference from surface turbulence. Acoustic data were thus

122 collected on a vertical range from 30 to $300 \mathrm{~m}$ according to the $120 \mathrm{kHz}$ range (Fig. 1). The

123 limited depth of $300 \mathrm{~m}$ is considered in the interpretation of mid-water organisms

124 distributions, especially for those which are known to perform vertical migration according to

125 the day/night cycle (diel vertical migration; Lebourges-Dhaussy et al., 2000; Benoit-Bird et

126 al., 2009) (see section 4.2 below). Indeed, most of these organisms were sampled at night but

127 only epipelagic and some mesopelagic organisms were observable during the day within this

128 depth range.

129 


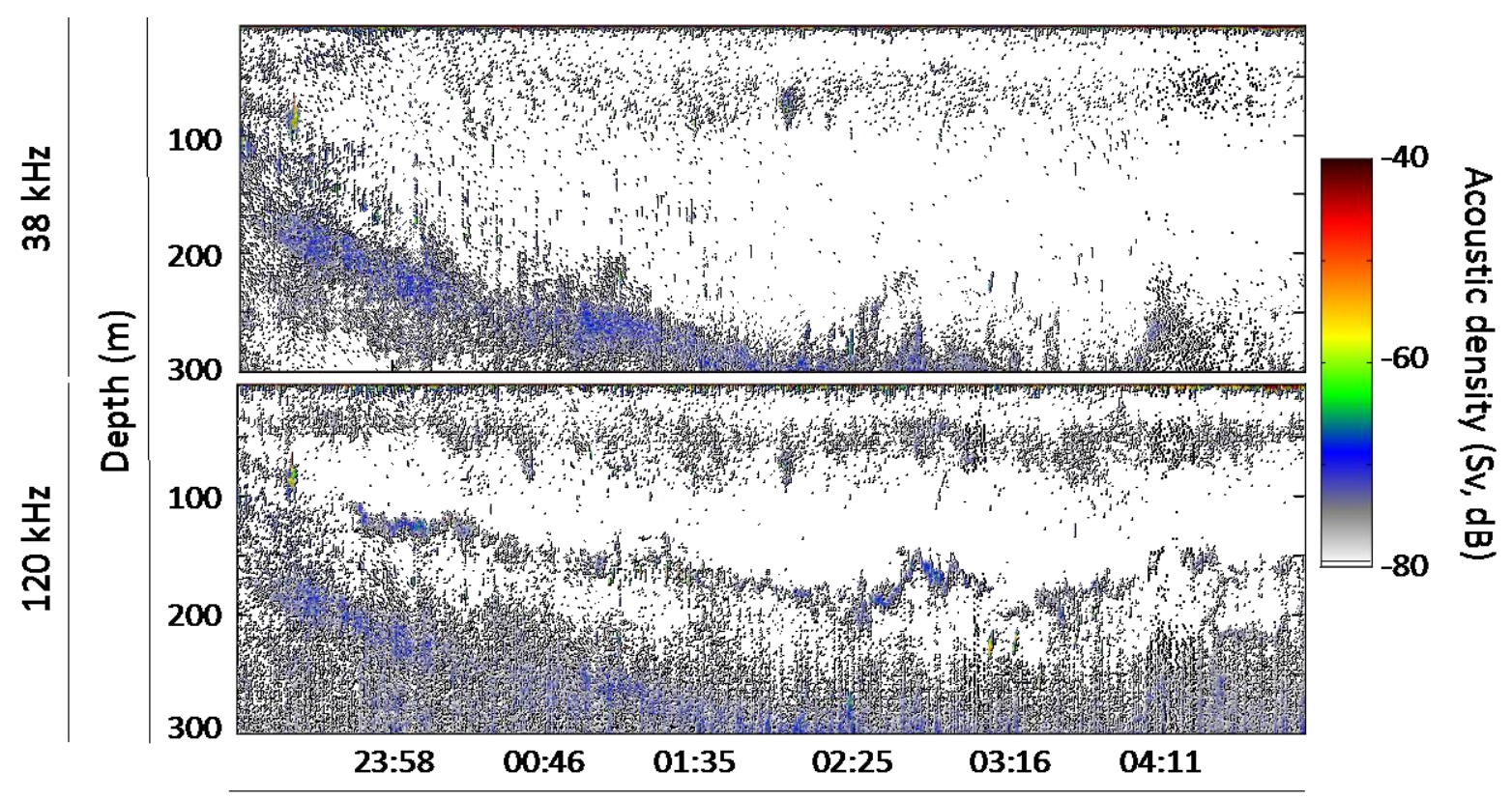

Time (GMT)

130 Fig. 1. 38 and $120 \mathrm{kHz}$ echograms representing acoustic density (in color, $\mathrm{S}_{\mathrm{v}}$ in $\mathrm{dB}$ ) recorded

131 on the $24^{\text {th }}$ of January 2014 morning from 30 to $300 \mathrm{~m}$ depth in east waters off Kerguelen.

Transducers were calibrated following the procedures recommended in Foote et al.

134 (1987). Settings that were used during data acquisition are summarized in Table 1. Movies+

135 software (Ifremer development) was used for assessing visually the quality of the data prior

136 further analyses. Depending on this quality assessment, data were filtered using an in-house

137 tool (Béhagle et al., 2015) computed with Matlab (MATLAB 7.11.0.584, Release 2010b) and

138 Movies3D software (Ifremer development) to remove ADCP (Acoustic Doppler Current

139 Profiler) interference, background noise, and both attenuated- and elevated-signals. Then, an

140 echo-integration by layer, with a threshold set at $-80 \mathrm{~dB}$ to exclude scatterers which are not

141 representative of micronektonic organisms, was applied on filtered acoustic data with an

142 echo-integration cell size fixed at 3 pings per $1 \mathrm{~m}$ depth in order to smooth variability while

143 keeping as much information as possible.

144 From echo-integration, volume backscattering strength $\left(S_{\mathrm{v}}, \mathrm{dB}\right.$ re $\left.1 \mathrm{~m}^{-1}\right)$ was used to

145 assess the mean echo level on both 38 and $120 \mathrm{kHz}$ and thus to evaluate differences of relative

146 frequency response of the organisms considered (see section 2.3 below). Also, the acoustic 
147 density of scatterers was estimated by calculating the Nautical Area Scattering Coefficient

148 (NASC, $\mathrm{s}_{\mathrm{A}}, \mathrm{m}^{2} \cdot \mathrm{nmi}^{-2}$; MacLennan et al., 2002). NASC was used as a proxy of relative

149 biomass of acoustic targets, assuming that the composition of the scattering layers and the

150 resulting scattering properties of biological organisms are homogeneous (e.g. Simmonds and

151 MacLennan, 2005; Lawson et al., 2008).

152

153 Table 1. Simrad EK60 echo sounder parameter settings onboard the R/V Marion Dufresne II

154 during the MD197/MYCTO cruise in January-February 2014.

\begin{tabular}{ccc}
\hline & $38 \mathrm{kHz}$ & $120 \mathrm{kHz}$ \\
& & \\
Max. power (W) & 1000 & 250 \\
Pulse duration (ms) & 1.024 & 1.024 \\
Ping interval (s) & 1.5 & 1.5 \\
Target Strength 'TS' gain (dB) & 24.65 & 27.03 \\
Area backscattering coefficient & -0.75 & -0.30 \\
(Sa) correction & 0.189 & 0.189 \\
Sample length (m) & & \\
\hline
\end{tabular}

155

156

2.2. Biological sampling

157

To determine the species and size composition of the dominant scatterers, trawling of

158 micronektonic animals was conducted using the Mesopelagos trawl that was designed by

159 Ifremer (fisheries biology and technology laboratory, LTBH, Lorient, France) (Meillat, 2012).

160 The non-closing trawl vertical and horizontal openings varied between 5 and $6 \mathrm{~m}$ and 10 and

$16112 \mathrm{~m}$, respectively. The trawl has a mesh size of $4 \mathrm{~cm}$ in the wings, reducing to $5 \mathrm{~mm}$ at the

162 codend during sampling. A terminal rigid collector was fixed on the codend in order to collect

163 micronektonic organisms in good conditions. A Scanmar acoustic device (Åsgårdstrand,

164 Norway) was attached on the net to monitor in real time the depth of trawling simultaneously

165 to acoustic measurements (Williams and Koslow, 1997). The net was also equipped with an 
elephant seal tag (Sea Mammal Research Unit, UK) that was fixed on the trawl headline. The

167 tag was a multisensor data logger recording pressure (accuracy of 2 dbar) and hence depth, temperature, salinity and fluorescence (Blain et al., 2013). Only depth data were analyzed in the present work, thus providing an accurate time/depth profile for each tow. The trawl was towed for $30 \mathrm{~min}$ at targeted depth at a speed of 1.5-2.5 knots. All catches were sorted by

171 species or lowest identifiable taxonomic groups, measured and weighed. While Antarctic krill

172 (Euphausia superba) does not occur in the area, collected taxa were representative of the

173 Polar Frontal Zone and Polar Front, including zooplankton-like organisms (i.e. euphausiids,

174 amphipods, large copepods and non-gaseous gelatinous organisms), fish-like organisms (i.e.

175 fish with a gas-filled swimbladder and gaseous gelatinous organisms), and other organisms

176 (i.e. fish without a gas-filled swimbladder and small squids). Most of the 39 pelagic hauls

177 conducted during this survey had mixed catches and were not further considered here. Indeed,

178 to be able to calibrate as correctly as possible a bi-frequency algorithm in this area, we chose

179 to use only mono-specific trawls. Two trawls were suitable for acoustic mark identification,

180 because almost all the catches consisted of one single species in large quantity (see section 2.3

181 below).

182

\subsection{Bi-frequency method calibration}

The acoustic properties of biological organisms vary with the operating frequency of the echo sounder. Therefore, comparing the echo levels of individual scatterers ensonified at different frequencies is likely to provide information on the types of targets that are present in

187 the water column (Madureira et al., 1993a,b; Kang et al., 2002). According to the literature, zooplankton-like and non-gaseous gelatinous organisms have an increasing relative frequency response between 38 and $120 \mathrm{kHz}$ (Stanton and Chu, 2000; David et al., 2001; Lavery et al., 
191 gelatinous organisms have a stable to decreasing relative frequency response between 38 and

$192120 \mathrm{kHz}$, depending on the size of the gaseous inclusion (Warren et al., 2001; Kloser et al.,

193 2002; Korneliussen and Ona, 2003) (Fig. 2). Thus, using the difference of reflectance of well-

194 characterized biological samples collected by trawls, we determined thresholds to obtain the

195 best compromise to separate three acoustic groups of organisms.

196

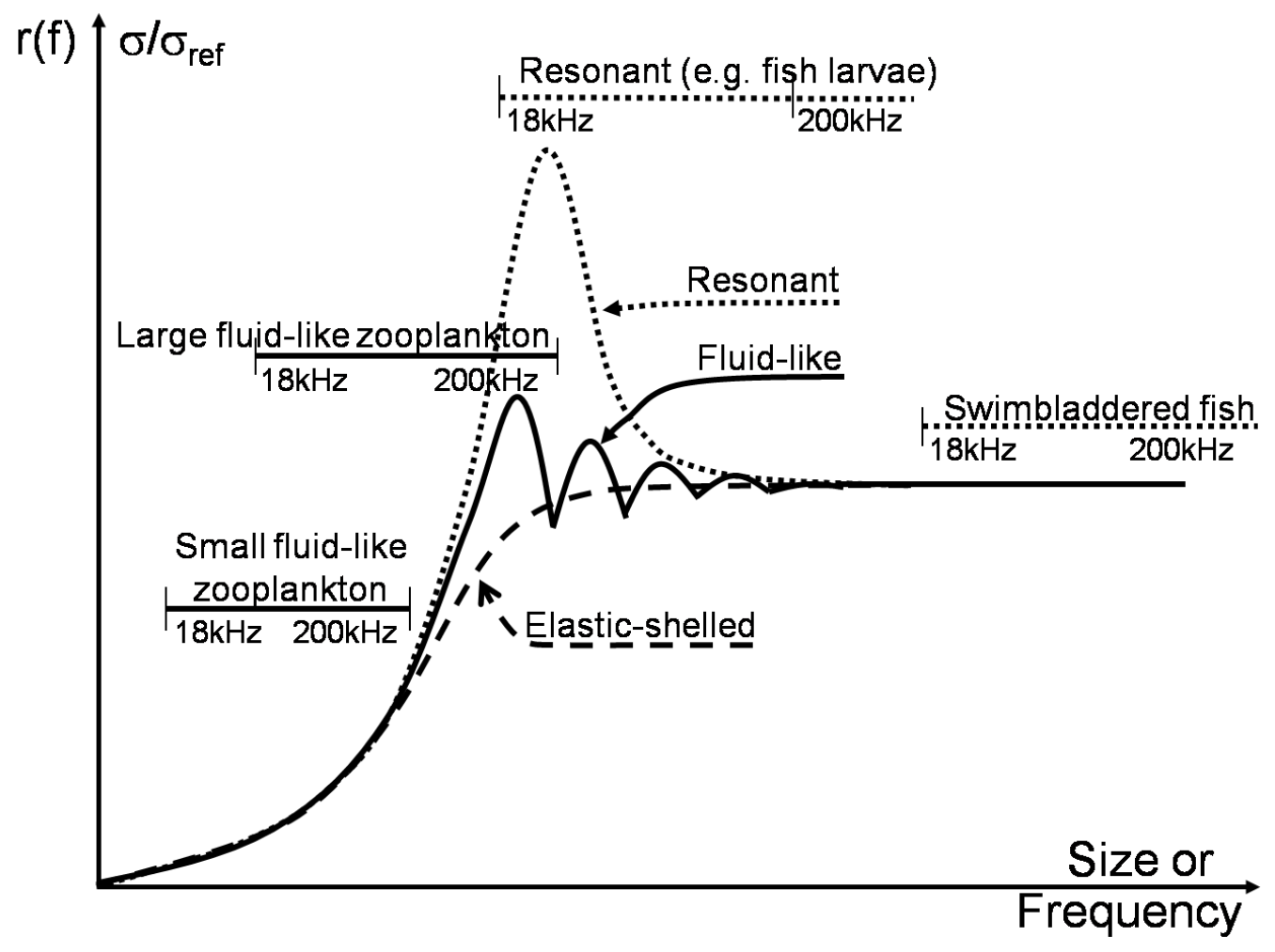

198 Fig. 2. Schematic description of the relative frequency response, $r(f)$. Horizontal lines indicate

199 typical range positions of selected acoustic categories when measured at frequencies 18-200

200 kHz. Source: Korneliussen and Ona (2003).

Firstly, "fluid-like" organisms were discriminated from "gas-bearing" organisms

203 according to trawl sampling and to acoustic properties of scatterers at 120 and $38 \mathrm{kHz}$, 204 respectively (Simmonds and MacLennan, 2005). Thresholds used in the bi-frequency 205 algorithm to discriminate acoustic groups were fixed using acoustic data from two relevant 
trawls, which were selected according to: $(i)$ their depth (only trawls between the surface and

$207200 \mathrm{~m}$ depth were considered to minimize as much as possible interference from the saturated 208 outgoing signal at $120 \mathrm{kHz}$ ), and (ii) the quality of their acoustic data (mainly depending on

209 the weather; only trawls with more than $50 \%$ of clean pings were considered). Two night 210 trawls (T07, $50 \mathrm{~m}$ depth and T14, $70 \mathrm{~m}$ depth) were mono-specific in their composition, 211 containing almost exclusively adults of subantarctic krill Euphausia vallentini (15-24 mm 212 long) and juveniles of the demersal fish Muraenolepis marmoratus (31-40 $\mathrm{mm}$ long), 213 respectively. The latter corresponds to the pelagic stage of the species (Duhamel et al., 2005), 214 i.e. fish were 3-4 cm long and contained a well-developed gas-filled swimbladder, similar to 215 several species of myctophids (Electrona carlsbergi, Krefftichthys anderssoni, 216 Protomyctophum spp.; Saunders et al., 2013). The acoustic characteristics of samples from 217 these two trawl tows were considered as representative of "fluid-like" and "gas-bearing" 218 scatterers, respectively. Only the acoustic characteristics corresponding in time and depth to 219 the two trawls were taken into account to grade the bi-frequency algorithm in order to be sure 220 that they were related to the organisms effectively caught in the net. For doing this, we used 221 the time/depth data provided by the elephant seal tag for extracting the acoustic data from $2 \mathrm{~m}$ 222 above the headline up to $10 \mathrm{~m}$ below (or $2 \mathrm{~m}$ below the footrope) during a limited time period 223 that focused on the acoustically detected aggregations (Fig. 3). The acoustic response at 38 224 and $120 \mathrm{kHz}$, of each echo-integration cell belonging to the trawl's path, was represented 225 relative to the $38 \mathrm{kHz}$ frequency (Fig. 4a) to assess the positive $v s$. negative slope of the 226 relative frequency response between discrete 38 and $120 \mathrm{kHz}$ frequencies. 


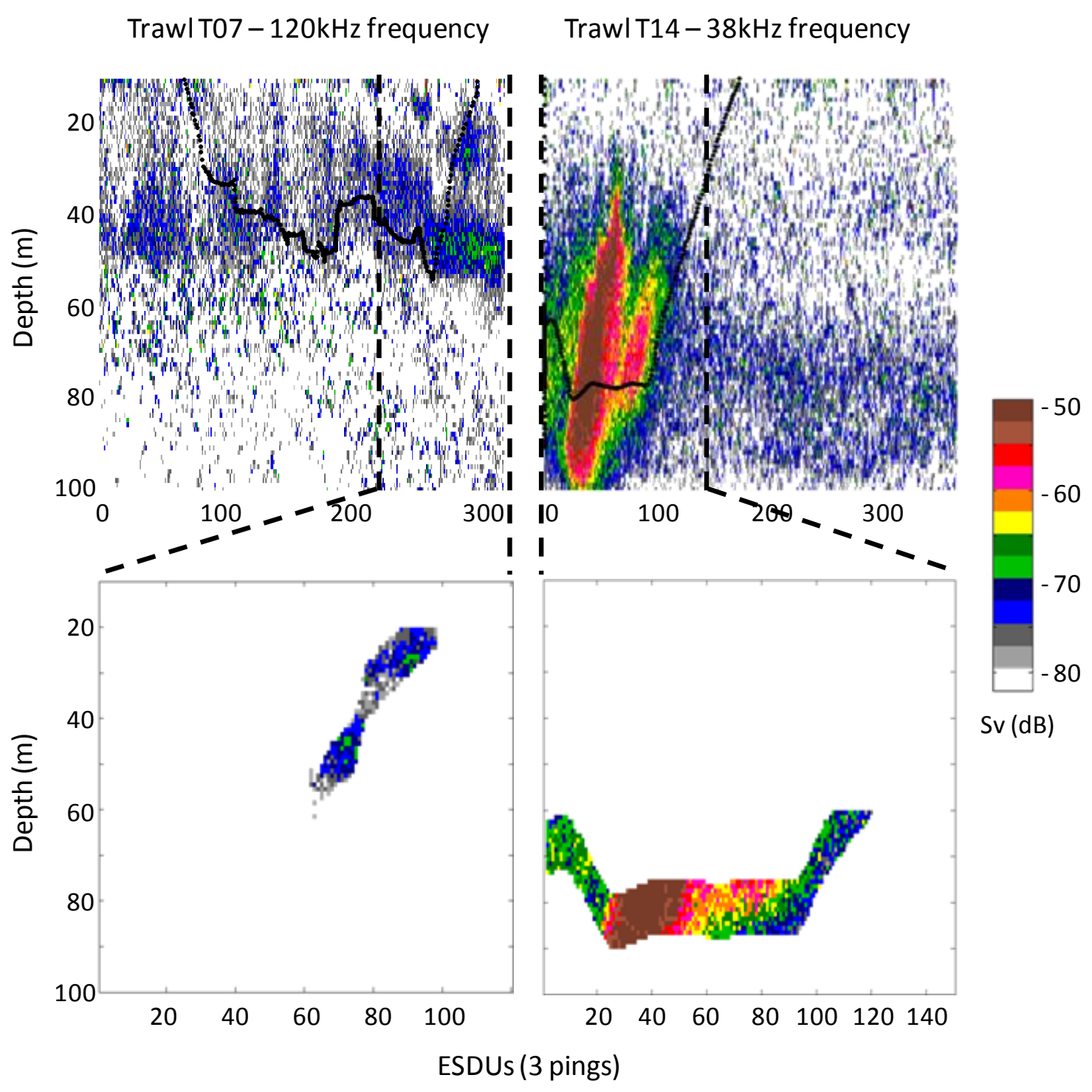

229 Fig. 3. Acoustic records and the corresponding cruise trawls (T07 and T14) that were used to

230 fix thresholds of difference in the bi-frequency algorithm. Upper panel: complete trawl

231 echograms with trawling depths (continuous black line) and limits of data extraction (dashed

232 black lines). Lower panel: extracted echogram samples focusing on the trawl targeted

233 aggregates that were selected from acoustic identification estimation. Left: T07 trawl

234 (euphausiids) sampling on the $120 \mathrm{kHz}$ frequency to discriminate the "fluid-like" group.

235 Right: T14 trawl (gas-filled swimbladder fish) on the $38 \mathrm{kHz}$ frequency to discriminate the 236 “gas-bearing” group. 
Secondly, the difference in relative frequency response $\left(\Delta S_{\mathrm{v}, 120-38}=S_{\mathrm{v}, 120}-S_{\mathrm{v}, 38}\right)$ was

evaluated per echo-integration cell using a varying threshold of difference, ranging from -15

241 classified either in a group "lower than the threshold considered" or in the opposite group

242 "higher than the threshold considered". The total acoustic density was calculated (on $120 \mathrm{kHz}$

243 samples for the "fluid-like" group and on $38 \mathrm{kHz}$ samples for the "gas-bearing" group) for 244 each of the lower/higher groups formed and reported in percentage to total acoustic density of 245 the aggregate for each tested threshold (Fig. 4b).

(a)

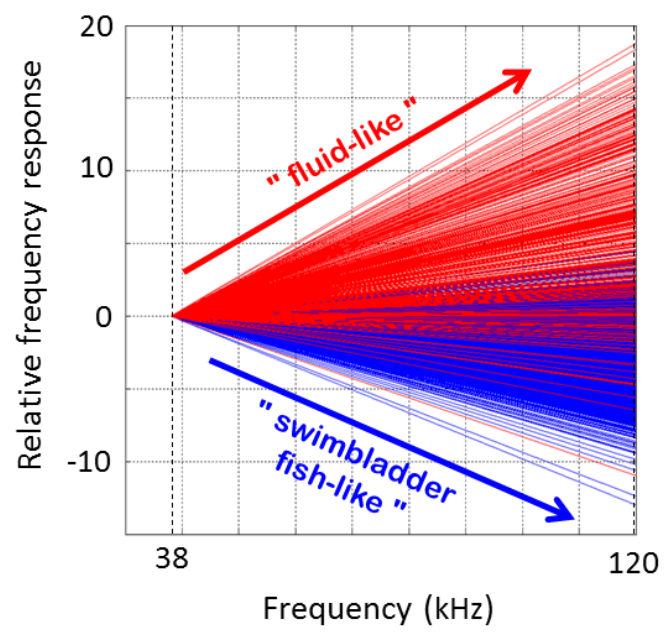

(b)

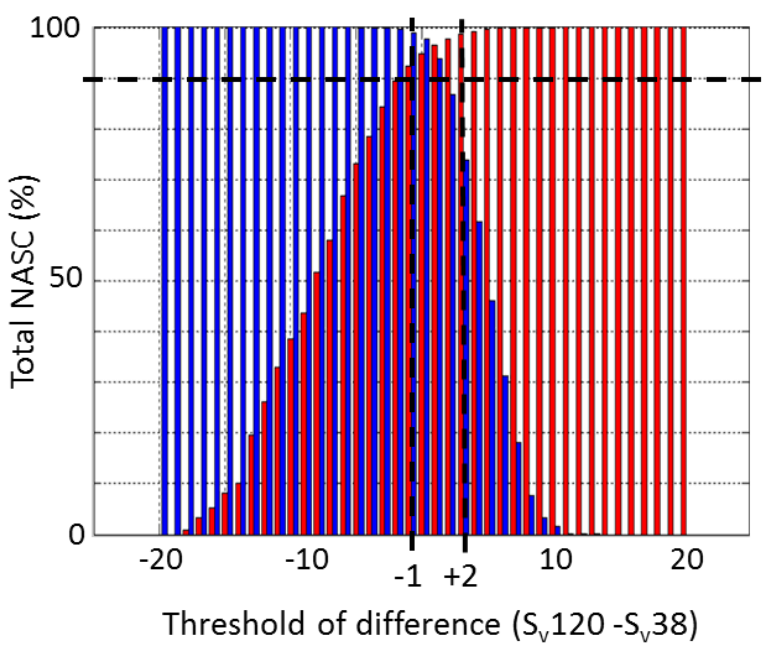

247 Fig. 4. Left panel (a): frequency response of each sample considered relatively to the $38 \mathrm{kHz}$ 248 frequency, with "fluid-like" samples (from the trawl T07) represented in red and "gas249 bearing" samples (from the trawl T14) in blue. Right panel (b): bar chart of the percentage of 250 "fluid-like" (in red) and "gas-bearing" (in blue) total NASC, according to a -15 to $25 \mathrm{~dB}$ range 251 of threshold of difference, used to define the best thresholds $(-1$ and $+2 \mathrm{~dB})$ delimiting the 252 "undetermined" group by transferring a maximum of $10 \%$ of their acoustic energy (total 253 NASC). 
Finally, the calculated "loss" of density for both "fluid-like" and "gas-bearing" groups 256 was used to define two thresholds of differences delimiting the "undetermined" group by 257 transferring a maximum of $10 \%$ of their acoustic energy (Fig. 4b) into the "undetermined" 258 group. This group corresponds to an uncertainty zone where scatterers $(i)$ have a close-to-flat 259 relative frequency response between discrete 38 and 120 frequencies, (ii) cannot be allocated 260 to "fluid-like" or "gas-bearing" organisms according to their $\mathrm{S}_{\mathrm{v}}$ difference measured between 26138 and $120 \mathrm{kHz}$ but (iii) are potentially present in the water column and (iv) have no 262 biological validation in this work. Preserving such a group allows accounting for organisms 263 that could not be identified during this work from biological sampling but are present in the 264 water column, while being more demanding on well-defined groups. Following this method, 265 thresholds were defined at -1 and $+2 \mathrm{~dB}$. Scatterers with $\Delta S_{\mathrm{v}, 120-38}(i)>+2 \mathrm{~dB}$ are classified in 266 the "fluid-like" group, $(i i)<-1 \mathrm{~dB}$ are classified in the "gas-bearing" group and (iii) between 2671 and $+2 \mathrm{~dB}$ are classified in a third "undetermined" group (Fig. 5). 


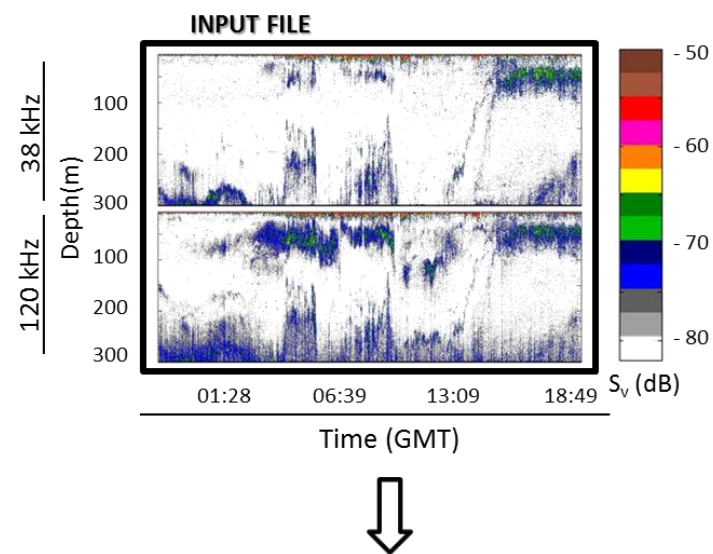

Frequency response comparatively to the $38 \mathrm{kHz}$
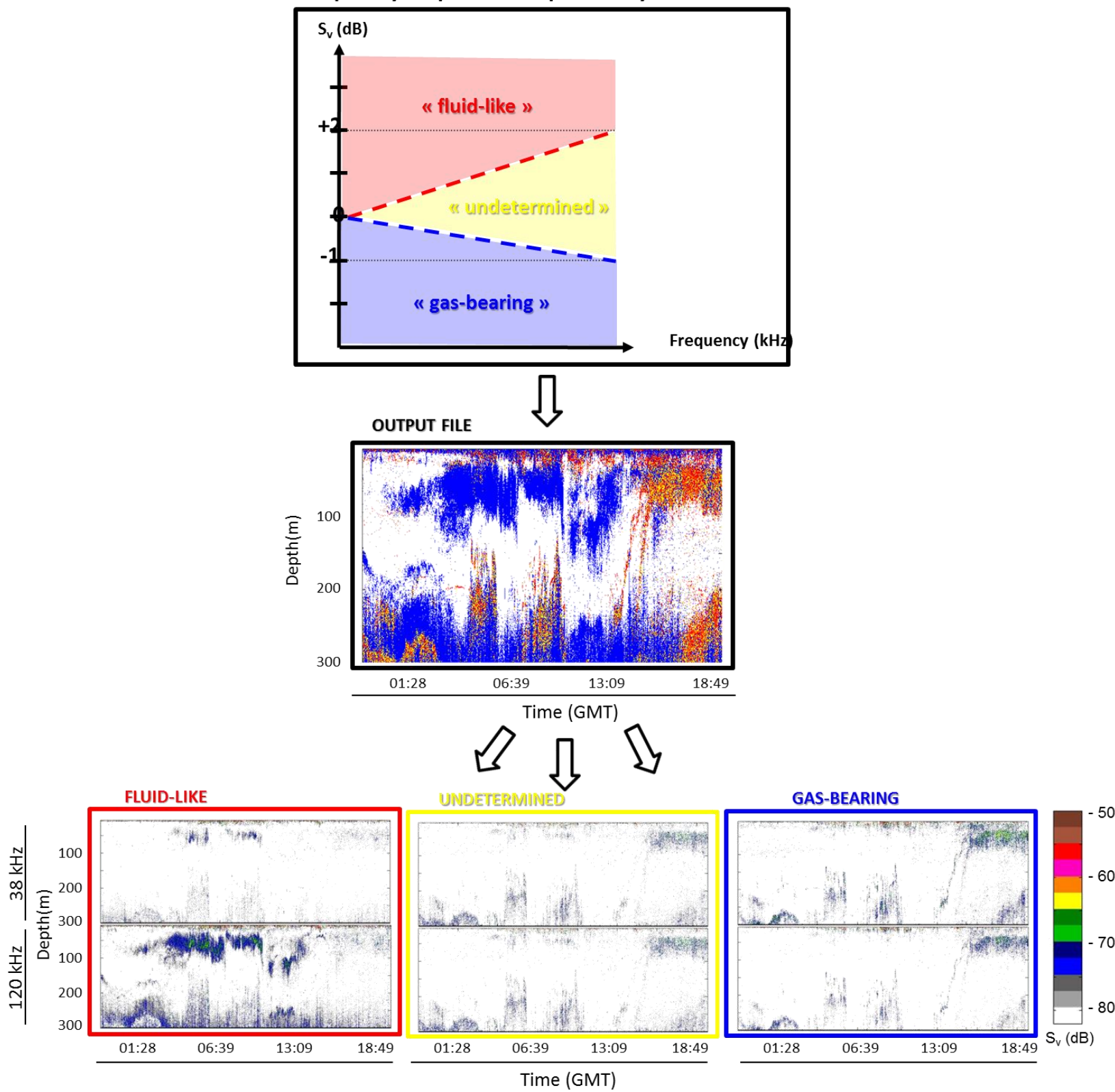

270 Fig. 5. Summary diagram of the bi-frequency algorithm method used in this study. 


\subsection{Testing the bi-frequency algorithm}

The robustness of threshold values obtained by the bi-frequency algorithm developed in the present work was tested by calculating the theoretical frequency responses of Muraenolepis marmoratus and Euphausia vallentini using the mathematical models of Ye (1997) and Stanton et al. (1994), respectively. While the Ye model provides an analytic method for studying scattering of "gas-bearing" organisms at low frequencies, the Stanton model focuses on the "fluid-like" organisms' acoustic properties.

The Ye (1997) model highlights a $\Delta S_{\mathrm{v}, 120-38}$ value of $-0.4 \mathrm{~dB}$ for fish of 3 to $4 \mathrm{~cm}$ length (as sampled during the T14 trawl), and the Stanton et al. (1994) model for randomlyoriented fluid, bent cylinder highlights a $\Delta S_{\mathrm{v}, 120-38}$ value of $+1.9 \mathrm{~dB}$ for euphausiids of $15-24$ mm length (length range of organisms sampled during the T07 trawl). Using the bi-frequency algorithm, the $\Delta S_{\mathrm{v}, 120-38}$ thresholds amounted to -1 and $+2 \mathrm{~dB}$, respectively, and are thus consistent with the results of mathematical models. Our threshold values were even stronger than those of the models $(-1<-0.4$ and $2>1.9 \mathrm{~dB})$, thus highlighting the selectivity of the algorithm. According to biological samples (see section 2.2. above) and acoustic properties of scatterers at 38 and $120 \mathrm{kHz}$ (see section 2.3 above), three acoustic groups have been defined for micronektonic organisms: (i) "gas-bearing" $\left(\Delta S_{\mathrm{v}, 120-38}<-1 \mathrm{~dB}\right)$, (ii) "fluid-like" $\left(\Delta S_{\mathrm{v}, 120-38}\right.$ $>2 \mathrm{~dB})$, and (iii) "undetermined" scatterers $\left(-1<\Delta S_{\mathrm{v}, 120-38}<2 \mathrm{~dB}\right)$.

\subsection{Data post-processing and statistical analyses}

Each echo-integration cell was attributed to "fluid-like", "undetermined" or "gasbearing" group based on its relative frequency response. Moreover, as living organisms follow non-random and non-uniform distributions (Margalef, 1979; Legendre and Fortin, 2004), acoustic data were analyzed separately in terms of patches and layers. 
First of all, in order to get homogenous horizontal sampling at high resolution, filtered data at 38 and $120 \mathrm{kHz}$ have been echo integrated in cells of $10 \mathrm{~m}$ (horizontal) by $1 \mathrm{~m}$ (vertical). Patches were here defined as isolated groups of echo-integrated cells limited in space (between 10 and $3000 \mathrm{~m}$ long) and associated to a mean volume backscattering strength $\mathrm{S}_{\mathrm{v}} \geq-63 \mathrm{~dB}$ on the mean 38 and $120 \mathrm{kHz}$ echogram. In contrast, layers were defined as continuous and homogenous areas of acoustic detections with a mean $S_{\mathrm{v}}<-63 \mathrm{~dB}$ for each 301 echo-integrated cell on the mean 38 and $120 \mathrm{kHz}$ echogram. The $-63 \mathrm{~dB}$ threshold was defined by the operator after a visual analysis of the number of patches detected along a representative acoustic sample of five hours long and along increasing $S_{\mathrm{v}}$ values from -70 to $40 \mathrm{~dB}$. The value of $-63 \mathrm{~dB}$ corresponds to a threshold level over which the number of patches did not further increased (Fig. 6).

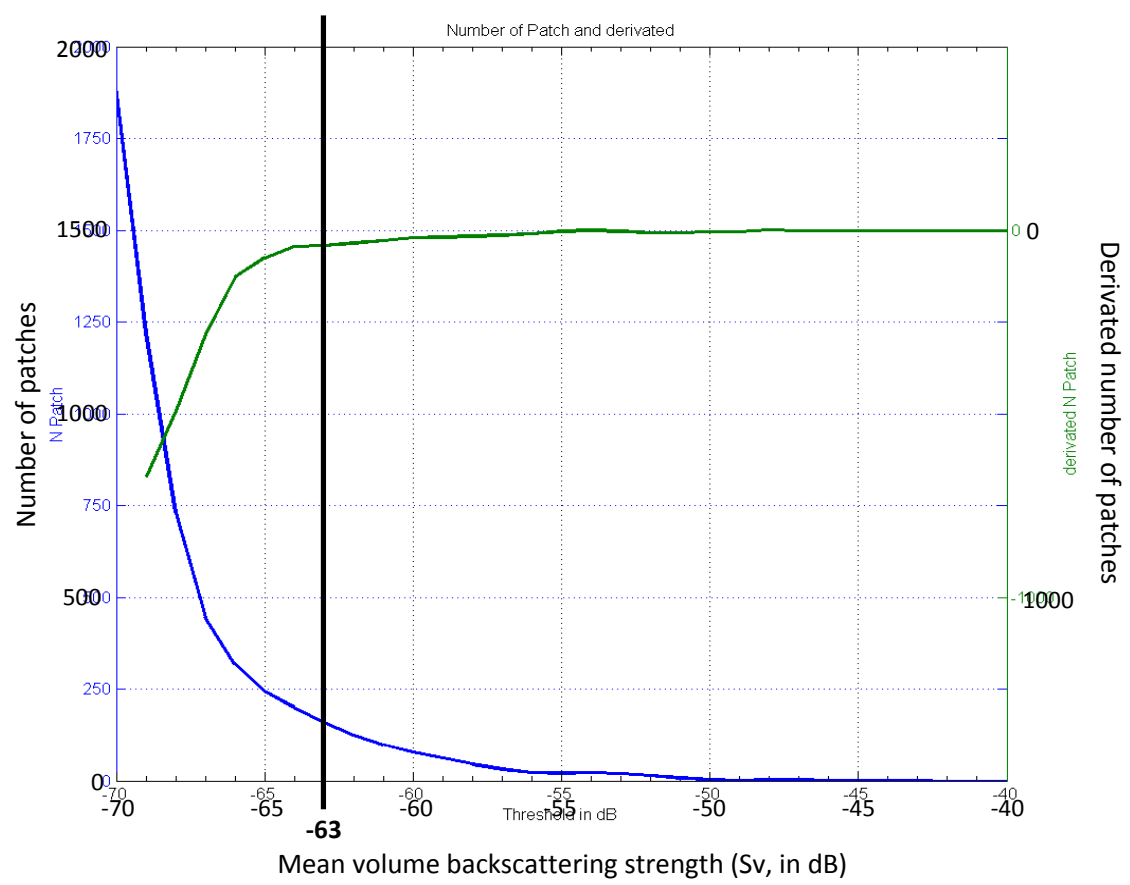

307 Fig. 6. Representative diagram of the number of patches (in blue) and its derivative (in green)

308 detected along increasing $S_{\mathrm{v}}$ values from -70 to $-40 \mathrm{~dB}$. The value of $-63 \mathrm{~dB}$ corresponds to a threshold level over which the number of patches did not further increased. 
312 were extracted from the echo integrated datasets and each contour considered as a detected 313 patch (Fig. 7a). For each patch, mean depth, vertical size, mean $\mathrm{S}_{\mathrm{v}}$ and mean NASC values at 314 both frequencies were computed. NASC values were first summed on the vertical and then 315 averaged on the horizontal. Cells that were not considered as patches were considered as 316 layers (Fig. 7b).

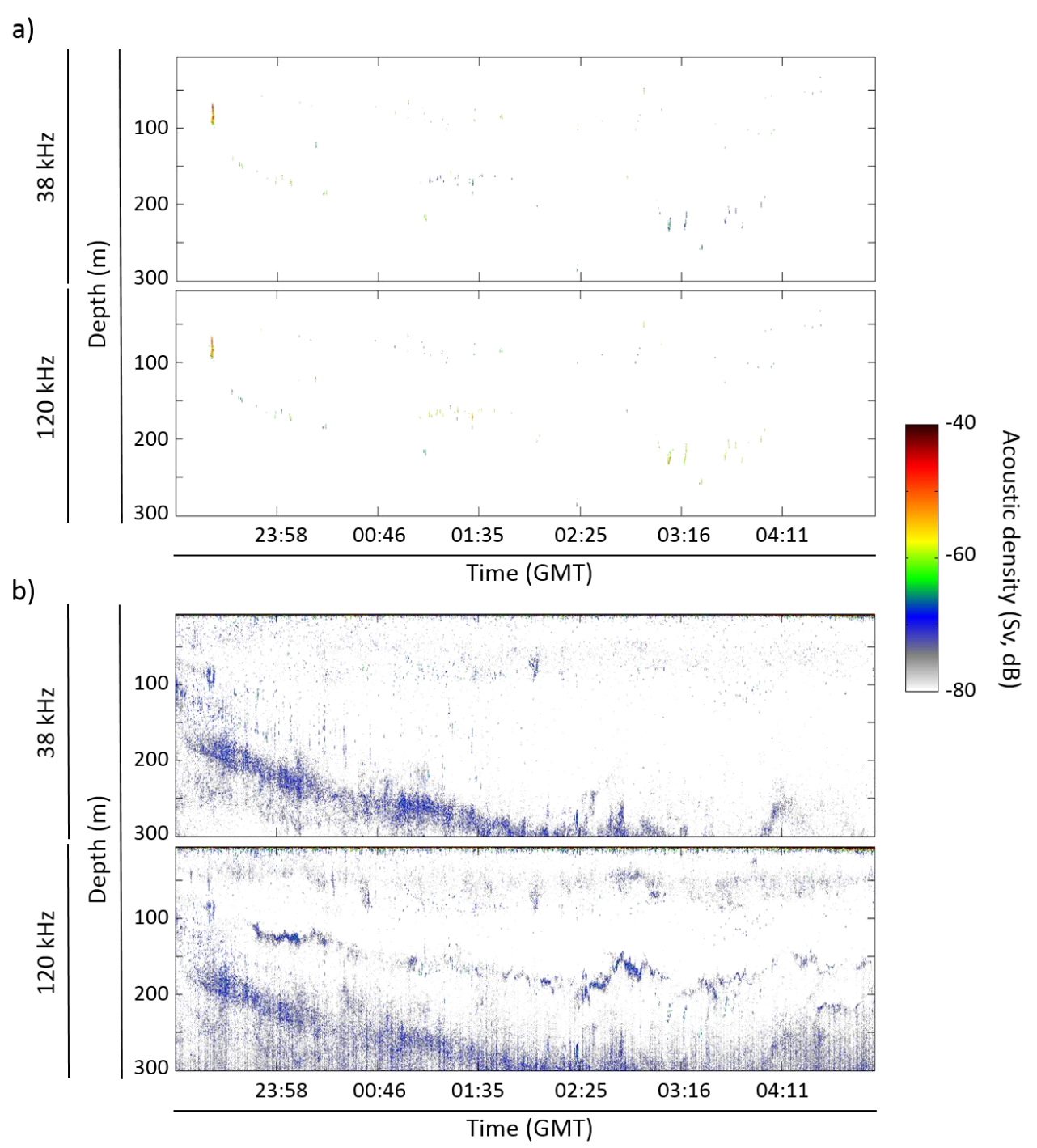

318 Fig. 7. 38 and $120 \mathrm{kHz}$ echograms representing acoustic density (in color, $\mathrm{S}_{\mathrm{v}}$ in $\mathrm{dB}$ ) recorded 319 on the $24^{\text {th }}$ of January 2014 morning from 30 to $300 \mathrm{~m}$ depth in east waters off Kerguelen for (a) patches- and (b) layers structures. 
Total-, patches- and layers- datasets were then post-processed following the same bi-

322 frequency algorithm (see section 2.3 above). Thus, nine datasets were obtained: "fluid-like", "gas-bearing", and "undetermined" for layer structures, for patch structures, and for the whole

324 (i.e. patches and layers together).

Acoustic data were analyzed from 30 to $300 \mathrm{~m}$ depth according to the applied offset

326 (see section 2.1. above) and the $120 \mathrm{kHz}$ emission range. Day and night data were analyzed 327 separately because many mid-water organisms undergo diel vertical migration. The crepuscular period (45 minutes before and after sunrise and sunset) during which mid-water

329 organisms ascend and descend (Lebourges-Dhaussy et al., 2000; Benoit-Bird et al., 2009)

330 were excluded from the analyses.

331 Statistical analyses were performed within the R environment (R Core Team, 2014).

332 Differences of distribution between groups were statistically assessed using student $\mathrm{t}$ tests. 


\section{Results}

\subsection{Horizontal distribution of acoustic groups of micronekton}

The horizontal distribution of NASC values (on $38 \mathrm{kHz}$ for "gas-bearing" and

337 "undetermined" groups; on $120 \mathrm{kHz}$ for "fluid-like" group) in the 30-300 m depth range

338 varied spatially (Northern and Southern tracks), and according to the daily cycle (day and

339 night), the type of structures (patches and layers) and the three acoustically-defined groups of

340 micronektonic organisms (Fig. 8, Tables 2 and 3). Several features were notable: (i) total

341 integrated NASC values were $2-3$ times higher in the Northern than in the Southern tracks;

342 (ii) with one exception (see below), NASC values of each group were higher at night than

343 during the day; (iii) a much larger proportion of scatterers of the three groups occurred in

344 layers than in patches; (iv) the layers/patches difference was more pronounced at day than

345 during the night, with patches almost disappearing at night ( $<1 \%$ of the total NASC values);

346 and $(v)$ during the day, a higher NASC proportion of "gas-bearing" (10-26\%) and

347 "undetermined" (10-34\%) than "fluid-like" (4-5\%) scatterers occurred in patches. 


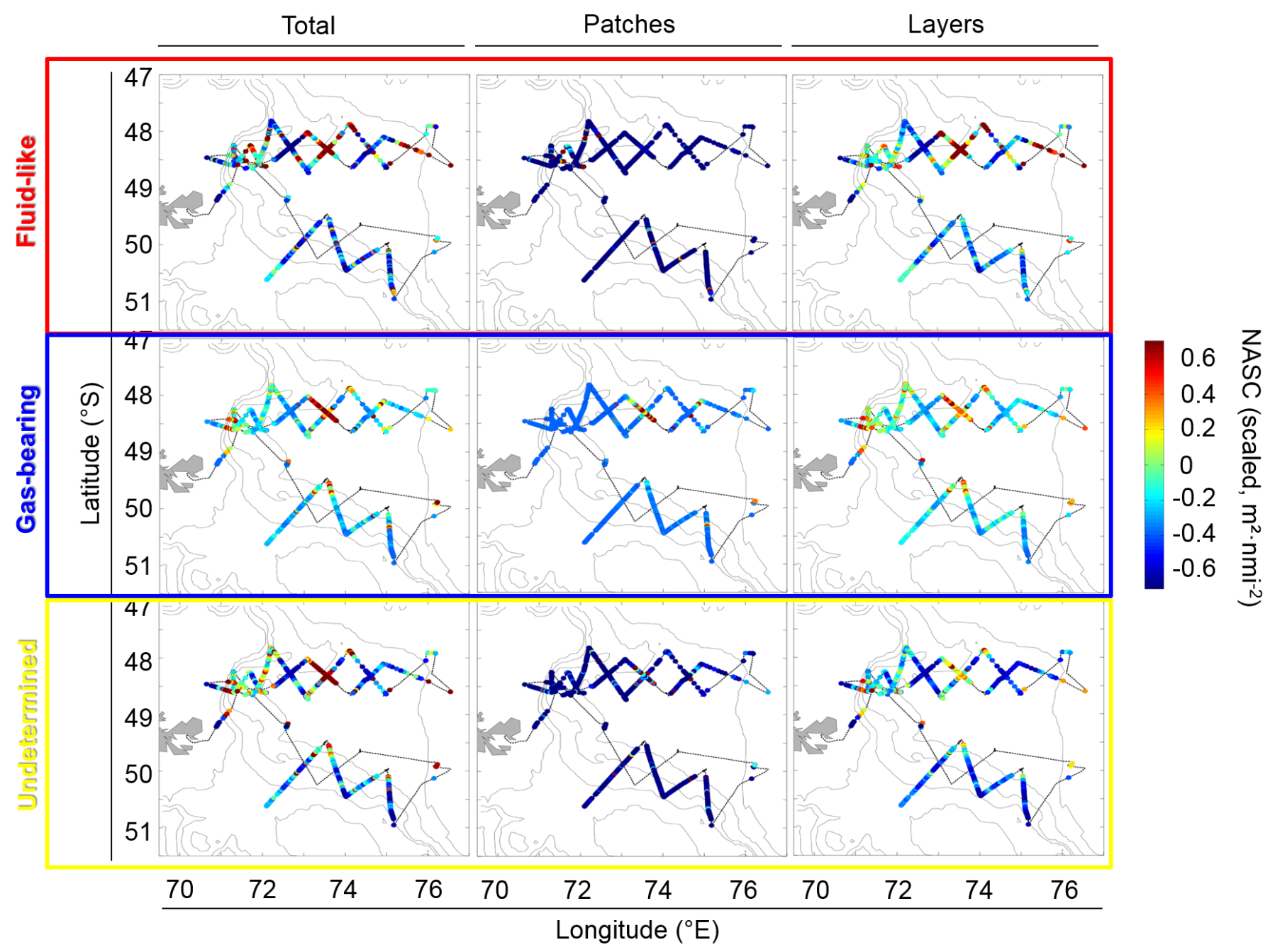

349

350 Fig. 8. Total density (NASC, scaled in $\mathrm{m}^{2} \cdot \mathrm{nmi}^{-2}$, colored on ship track) observed during the cruise integrated from 30 to $300 \mathrm{~m}$ depth for each acoustic group ("gas-bearing", fluid-like" and "undetermined" groups) and for each type of structure (patches and layers). 
Table 2. Acoustic density (NASC, in $\mathrm{m}^{2} \cdot \mathrm{nmi}^{-2}$ ) per echo-integration cell of each acoustic group ("gas-bearing", "fluid-like" and "undetermined"

\begin{tabular}{|c|c|c|c|c|c|c|}
\hline Time period & Tracks & $\begin{array}{l}\text { Echo-integration } \\
\text { cell per } 10 \mathrm{~m}(\mathrm{n})\end{array}$ & $\begin{array}{l}\text { Total NASC values at } \\
38 \text { or } 120 \mathrm{~Hz}\left(\mathrm{~m}^{2} \cdot \mathrm{nm}^{-2}\right)\end{array}$ & $\begin{array}{l}\text { "Fluid-like" NASC values } \\
\text { at } 120 \mathrm{kHz}\left(\mathrm{m}^{2} \cdot \mathrm{nm}^{-2}\right)\end{array}$ & $\begin{array}{c}\text { "Gas-bearing" NASC } \\
\text { values at } 38 \mathrm{kHz}\left(\mathrm{m}^{2} \cdot \mathrm{nm}^{-2}\right)\end{array}$ & $\begin{array}{c}\text { "Undetermined" NASC } \\
\text { values at } 38 \mathrm{kHz}\left(\mathrm{m}^{2} \cdot \mathrm{nm}^{-2}\right)\end{array}$ \\
\hline \multirow[t]{3}{*}{ Day } & Northern & 69150 & $446 \pm 3402$ & $283 \pm 2641$ & $107 \pm 1073$ & $56 \pm 756$ \\
\hline & Southern & 37724 & $273 \pm 1642$ & $209 \pm 1507$ & $42 \pm 563$ & $22 \pm 136$ \\
\hline & Both tracks & 106874 & $385 \pm 2907$ & $257 \pm 2305$ & $84 \pm 372$ & $44 \pm 614$ \\
\hline \multirow[t]{3}{*}{ Night } & Northern & 15252 & $649 \pm 3091$ & $351 \pm 2432$ & $225 \pm 1487$ & $73 \pm 454$ \\
\hline & Southern & 5065 & $195 \pm 579$ & $73 \pm 431$ & $84 \pm 372$ & $38 \pm 32$ \\
\hline & Both tracks & 20317 & $536 \pm 2701$ & $282 \pm 2122$ & $190 \pm 1303$ & $64 \pm 394$ \\
\hline \multirow[t]{3}{*}{ Day and night } & Northern & 84402 & $483 \pm 3349$ & $295 \pm 2604$ & $129 \pm 1160$ & $59 \pm 711$ \\
\hline & Southern & 42789 & $264 \pm 1555$ & $193 \pm 1423$ & $47 \pm 544$ & $24 \pm 128$ \\
\hline & Both tracks & 127191 & $409 \pm 2875$ & $261 \pm 2277$ & $101 \pm 998$ & $47 \pm 584$ \\
\hline
\end{tabular}


361 Table 3. Acoustic density (NASC, in $\mathrm{m}^{2} \cdot \mathrm{nmi}^{-2}$ ) summed in the $30-300 \mathrm{~m}$ depth range and

362 percentage contributions (between brackets) of each acoustic group ("gas-bearing", "fluid-

363 like" and "undetermined" groups) as patches and layers (see text for definitions). Daytime and

364 nighttime were considered separately, as the Northern and Southern tracks were.

\begin{tabular}{|c|c|c|c|c|c|c|c|}
\hline \multirow{2}{*}{ Tracks } & \multirow[t]{2}{*}{ Groups } & \multicolumn{3}{|c|}{ Day } & \multicolumn{3}{|c|}{ Night } \\
\hline & & $\begin{array}{c}\text { Total } \\
\left(10^{6} \mathrm{~m}^{2} \mathrm{nmi}^{-2}\right)\end{array}$ & $\begin{array}{c}\text { Patches } \\
(\%)\end{array}$ & $\begin{array}{c}\text { Layers } \\
(\%)\end{array}$ & $\begin{array}{c}\text { Total } \\
\left(10^{6} \mathrm{~m}^{2} \mathrm{nmi}^{-2}\right)\end{array}$ & $\begin{array}{c}\text { Patches } \\
(\%)\end{array}$ & $\begin{array}{c}\text { Layers } \\
(\%)\end{array}$ \\
\hline \multirow[t]{4}{*}{ Northern } & Gas-bearing & $11.68(25.9)$ & 10.3 & 89.7 & $5.64(32.0)$ & 0.8 & 99.2 \\
\hline & Fluid-like & $29.30(65.0)$ & 4.7 & 95.3 & $10.41(59.1)$ & 0.8 & 99.2 \\
\hline & Undetermined & $4.10(9.1)$ & 9.7 & 90.3 & $1.56(8.9)$ & 0.7 & 99.3 \\
\hline & Total & $45.08(100.0)$ & 6.6 & 93.4 & $17.61(100.0)$ & 0.8 & 99.2 \\
\hline
\end{tabular}

\begin{tabular}{|c|c|c|c|c|c|c|c|}
\hline Southern & Gas-bearing & $2.23(12.9)$ & 26.1 & 73.9 & $0.68(44.4)$ & 0.5 & 99.5 \\
\hline & Fluid-like & $14.21(82.2)$ & 3.4 & 96.6 & $0.66(43.2)$ & 0.0 & 100.0 \\
\hline & Undetermined & $0.85(4.9)$ & 34.0 & 66.0 & $0.19(12.5)$ & 0.2 & 99.8 \\
\hline & Total & $17.30(100.0)$ & 7.9 & 92.1 & $1.53(100.0)$ & 0.2 & 99.8 \\
\hline
\end{tabular}

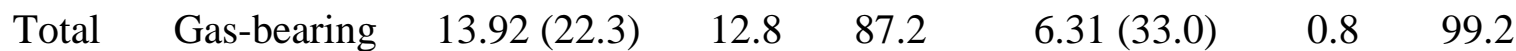

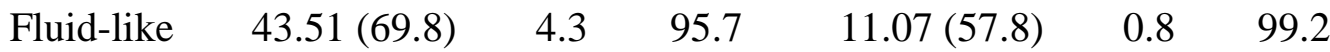

$\begin{array}{lllllll}\text { Undetermined } & 4.95(7.9) & 13.9 & 86.1 & 1.75(9.2) & 0.6 & 99.4\end{array}$

$\begin{array}{lllllll}\text { Total } & 62.38(100.0) & 6.9 & 93.1 & 19.14(100.0) & 0.8 & 99.2\end{array}$


The vertical distribution of NASC values of the three acoustically-defined groups of micronektonic organisms varied spatially (Northern and Southern tracks), temporally (time of 370 the day), and according to the type of structures (patches and layers) (Fig. 9, Table 4). 371 Overall, "fluid-like" organisms were structured in layers and their NASC values showed: $(i)$ a 372 peak at shallow depths $(<100 \mathrm{~m})$ during the day with an intermediate inter-quartile range revealing a rather unimodal vertical distribution; and (ii) a progressive increase with depth

374 from 150 to $300 \mathrm{~m}$. The pattern was similar at night, but with significantly lower values $(\mathrm{t}=$ $17.5, \mathrm{p}<0.001)$ and higher inter-quartile range, highlighting a consistent distribution in the range 30-300 m. "Gas-bearing" scatterers showed a different vertical pattern with a welldefined change between day and night. While most scatterers were structured in layers, they were more patchily distributed during the day with a main mode at $\sim 150$ and $\sim 70 \mathrm{~m}$ in the Northern and Southern tracks, respectively. Patches almost completely disappeared at night during which "gas-bearing" organisms occurred in more diffuse layers with a unimodal

381 distribution in the north at $\sim 30 \mathrm{~m}$ and a bimodal distribution in the south at $\sim 65$ and $\sim 200 \mathrm{~m}$.

382 The distribution of "undetermined" organisms showed no obvious patterns, with discrete small patches during the day and more obvious layers at night, especially at shallow depths in the Northern track (Fig. 9, Table 4). 

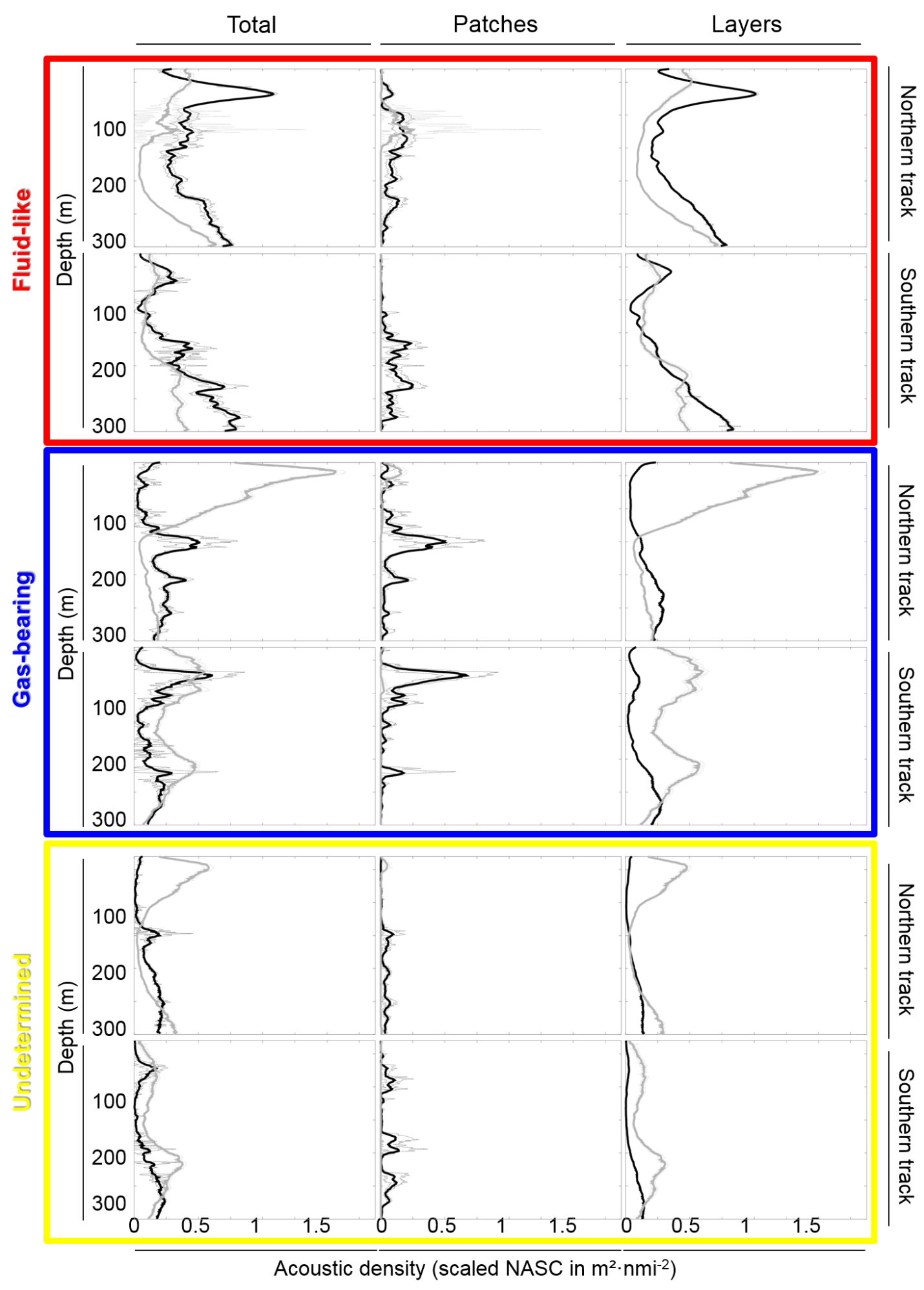

386 Fig. 9. Mean vertical NASC profiles from 30 to $300 \mathrm{~m}$ depth of each acoustic group ("gas-

387 bearing", fluid-like" and "undetermined" groups) for day (black lines) and night (grey lines)

388 and for each type of structures (patches and layers). Dashed lines indicate the $95 \%$ confidence

389 intervals. 
390 Table 4. Maximum acoustic density (NASC) depth, median acoustic density and inter-

391 quantile range proportion of acoustic groups (calculated on the $38 \mathrm{kHz}$ for the "gas-bearing"

392 and "undetermined" groups and on the $120 \mathrm{kHz}$ for the "fluid-like" group) according to the

393 tracks (Northern and Southern), time of the day (day and night) and type of structures

394 (patches and layers).

\begin{tabular}{|c|c|c|c|c|c|}
\hline Timing & Tracks & Groups & $\begin{array}{c}\text { Maximum NASC } \\
\text { depth (m) }\end{array}$ & $\begin{array}{l}\text { Median NASC values } \\
\qquad\left(\mathrm{m}^{2} \mathrm{nmi}^{-2}\right)\end{array}$ & $\begin{array}{c}\text { Inter-quantile } \\
\text { range }(\%)\end{array}$ \\
\hline \multicolumn{6}{|l|}{ Total } \\
\hline \multirow[t]{6}{*}{ Day } & \multirow[t]{3}{*}{ Northern } & Gas-bearing & 148 & 0.16 & 24.6 \\
\hline & & Fluid-like & 66 & 0.36 & 23.9 \\
\hline & & Undetermined & 147 & 0.09 & 50.0 \\
\hline & \multirow[t]{3}{*}{ Southern } & Gas-bearing & 72 & 0.11 & 19.3 \\
\hline & & Fluid-like & 275 & 0.23 & 47.7 \\
\hline & & Undetermined & 270 & 0.05 & 54.5 \\
\hline \multirow[t]{6}{*}{ Night } & \multirow[t]{3}{*}{ Northern } & Gas-bearing & 42 & 0.13 & 27.3 \\
\hline & & Fluid-like & 295 & 0.20 & 50.0 \\
\hline & & Undetermined & 45 & 0.10 & 33.3 \\
\hline & \multirow[t]{3}{*}{ Southern } & Gas-bearing & 65 & 0.23 & 34.7 \\
\hline & & Fluid-like & 294 & 0.13 & 54.3 \\
\hline & & Undetermined & 214 & 0.12 & 25.0 \\
\hline \multicolumn{6}{|l|}{ Patches } \\
\hline \multirow{6}{*}{ Day } & \multirow[t]{3}{*}{ Northern } & Gas-bearing & 147 & 0.03 & 10.4 \\
\hline & & Fluid-like & 109 & 0.05 & 17.1 \\
\hline & & Undetermined & 143 & 0.02 & 30.0 \\
\hline & \multirow[t]{3}{*}{ Southern } & Gas-bearing & 68 & 0.01 & 9.7 \\
\hline & & Fluid-like & 163 & 0.02 & 36.4 \\
\hline & & Undetermined & 194 & 0.01 & 27.8 \\
\hline \multirow[t]{6}{*}{ Night } & \multirow[t]{3}{*}{ Northern } & Gas-bearing & 45 & 0.00 & 7.1 \\
\hline & & Fluid-like & 122 & 0.00 & 0.0 \\
\hline & & Undetermined & 41 & 0.00 & 0.0 \\
\hline & \multirow[t]{3}{*}{ Southern } & Gas-bearing & 94 & 0.00 & 0.0 \\
\hline & & Fluid-like & 38 & 0.00 & 0.0 \\
\hline & & Undetermined & 58 & 0.00 & 0.0 \\
\hline \multicolumn{6}{|l|}{ Layers } \\
\hline \multirow[t]{6}{*}{ Day } & \multirow[t]{3}{*}{ Northern } & Gas-bearing & 230 & 0.13 & 59.3 \\
\hline & & Fluid-like & 65 & 0.31 & 32.9 \\
\hline & & Undetermined & 297 & 0.04 & 53.8 \\
\hline & \multirow[t]{3}{*}{ Southern } & Gas-bearing & 263 & 0.07 & 54.2 \\
\hline & & Fluid-like & 292 & 0.21 & 39.7 \\
\hline & & Undetermined & 297 & 0.02 & 46.2 \\
\hline \multirow[t]{6}{*}{ Night } & \multirow[t]{3}{*}{ Northern } & Gas-bearing & 42 & 0.14 & 27.7 \\
\hline & & Fluid-like & 294 & 0.22 & 45.3 \\
\hline & & Undetermined & 45 & 0.09 & 36.6 \\
\hline & \multirow[t]{3}{*}{ Southern } & Gas-bearing & 65 & 0.28 & 33.3 \\
\hline & & Fluid-like & 294 & 0.19 & 53.7 \\
\hline & & Undetermined & 214 & 0.10 & 27.6 \\
\hline
\end{tabular}




\section{Discussion}

Historically, most of the acoustic investigations conducted in the Southern Ocean since the 1960s focused on Antarctic krill (Demer and Conti, 2005; Fielding et al., 2014), due

to its high and variable biomass (Atkinson et al., 2009), key role in the high-latitude pelagic ecosystem (Ainley and DeMaster, 1990) and developing commercial fisheries (Nicol et al., 2012). More recently, the concept of a distinct Antarctic open-ocean food chain where Antarctic krill is absent pointed out the importance of other micronektonic organisms, including mid-water fish (Rodhouse and White, 1995). Hence, different groups were

404 405 acoustically characterized in the Antarctic krill zone (Fielding et al., 2012; Saunders et al., 2013), but, to our knowledge, little acoustic information is available in Northern waters of the Southern Ocean where Antarctic krill is ecologically replaced by other micronektonic organisms, namely euphausiids, a few hyperiid amphipods and myctophid fishes.

The present study focused on productive waters off eastern Kerguelen Islands, where numerous top predators target micronektonic organisms different from Antarctic krill (Guinet et al. 1996). It provides a first depiction of horizontal and vertical (30-300 m) distribution and abundance of three different acoustic groups of micronektonic organisms from a bi-frequency processing of acoustic data (38 and $120 \mathrm{kHz})$.

\subsection{Methodological comments and biological interpretation of the acoustic groups}

Methodologically, the frequency-dependent technique based on estimated differences between mean volume-backscattering strength at 38 and $120 \mathrm{kHz}$ has also previously been used to characterize acoustic groups (Madureira 1993a,b; Brierley et al., 1998). The most recent investigations defined two micronektonic groups in Antarctic waters, namely Antarctic 
krill (macrozooplankton) that was identified using a 2-12 or 2-16 $\mathrm{dB} \Delta S_{\mathrm{v}, 120-38}$ window

421 (Fielding et al., 2012, 2014), and myctophids (gas-filled swimbladder fish) that were 422 characterized by $\Delta S_{\mathrm{v}, 120-38}<2$ or $<0 \mathrm{~dB}$ (Fielding et al., 2012; Saunders et al. 2013). 423 Elsewhere, a threshold at $\Delta S_{\mathrm{v}, 120-38}=2 \mathrm{~dB}$ was used to discriminate gas-filled swimbladder 424 fish (<2 dB) from euphausiids ( $>2 \mathrm{~dB}$ ) (De Robertis et al., 2010; Ressler et al., 2015). Using 425 the same overall approach, our $\Delta S_{\mathrm{v}, 120-38}$ threshold values fit well with theoretical models (Ye, 426 1997; Stanton et al., 1994). The $\Delta S_{\mathrm{v}, 120-38}$ threshold value $(-1 \mathrm{~dB})$ to discriminate "gas427 bearing" backscatters was even lower than the previously used values (0-2 dB). Hence, our 428 identification of "gas-bearing" backscatters is more conservative than in previous 429 investigations, and the method allowed discriminating a third intermediate group of 430 backscatters at $-1<\Delta S_{\mathrm{v}, 120-38}<2 \mathrm{~dB}$ that cannot be classified as a given type of organism 431 without ground-truthing. Micronektonic organisms that constituted the three acoustic groups of backcatters can 433 be tentatively defined using a combination of bi-frequency threshold values, acoustic 434 sampling depth (30-300 m), net sampling (Hunt et al., 2011) and predators' diet (Guinet et al., 435 1996) within the studied area. (i) The "fluid-like" group $\left(\Delta S_{\mathrm{v}, 120-38}>2 \mathrm{~dB}\right)$ is likely to 436 correspond primarily to crustaceans, including euphausiids (e.g. Euphausia vallentini, E. 437 triacantha, Thysanoessa spp.) and hyperiids (Themisto gaudichaudii). Non-gas-bearing 438 gelatinous organisms (e.g. salps) also occur in the area (Hunt et al., 2011) and they were 439 collected during the cruise, it is here assumed that their acoustic signature was similar to 440 "fluid-like" signature (Wiebe et al., 2010). (ii) The "gas-bearing" group $\left(\Delta S_{\mathrm{v}, 120-38}<-1 \mathrm{~dB}\right)$ 441 includes gas-bearing gelatinous organisms and gas-filled swimbladder fish. Siphonophores 442 occur in the Southern Ocean, but their abundance is relatively low in Kerguelen waters (Hunt 443 et al., 2011). On the other hand, mesopelagic fish were abundant, with most of them 444 belonging to the Family Myctophidae in terms of species, number and biomass (Duhamel et 
al., 2005). Not all myctophid species contain a gas-filled swimbladder, however, and it is

446 likely that the acoustically detected myctophids were primarily Electrona carlsbergi,

447 Krefftichthys anderssoni and Protomyctophum spp. although it was not possible to

448 differentiate between species (Marshall, 1960; Saunders et al., 2013). Noticeably, all those

449 species are targeted by the myctophid-eater king penguin (Bost et al., 2002; Cherel et al.,

450 2002) and they are known to form school structures (Saunders et al., 2013). Krefftichthys

451 anderssoni was the commonest net-caught myctophid during the cruise and Protomyctophum

452 bolini and P. tenisoni also occurred in significant numbers in trawls (authors' unpublished

453 data). (iii) The "undetermined" group of scatterers $\left(-1<\Delta S_{\mathrm{v}, 120-38}<2 \mathrm{~dB}\right)$ most likely

454 corresponds to other fish, meaning lipid-filled swimbladder species and fish with no

455 swimbladder (Simmonds and MacLennan, 2005). Again these characteristics point out

456 myctophid fish in the area, including Gymnoscopelus braueri that ranked third amongst the

457 net-caught myctophids during the cruise (authors' unpublished data) together with other

458 Gymnoscopelus species that constitute the main prey species of fur seals Arctocephalus spp.

459 (Marshall, 1960; Lea et al., 2002; Saunders et al., 2013). Theoretically also, the

460 "undetermined" group can include a combination of "fluid-like" and "gas-bearing" scatterers

461 living in mixed and homogenous layers or patches, thus overall resulting in intermediate

$462 \Delta S_{\mathrm{v}, 120-38}$ values.

463

\subsection{Horizontal and vertical distribution of the acoustic groups}

The acoustic density (NASC) of micronektonic scatterers varied both in time and

467 space, thus showing a complex pattern depending on acoustically-defined groups, time of the 468 day (day/night), depth (30-300 m), the type of structures (patches and layers) and geography 469 (Northern and Southern tracks). Firstly, depth-integrated NASC values of the three acoustic 
groups were higher in the Northern than the Southern tracks, which may correspond to the

471 Polar Front and Northern Antarctic waters, respectively. This would be consistent with the 472 high abundance of micronekton recorded in frontal areas of the Western Indian sector of the 473 Southern Ocean (Pakhomov et al., 1996; Pakhomov and Froneman, 2000) and deserves a 474 thorough study in combination with hydrographic data. Secondly, the finding of an overall 475 higher biomass at night than during the day is in accordance with a recent large-scale acoustic 476 investigation in the Western Indian Ocean (Béhagle et al. 2015) and the general trend of 477 upward migration of deep-dwelling zooplanktonic and micronektonic organisms at sunset in oceanic waters (Domokos, 2009; Escobar-Flores et al., 2013; Béhagle et al., 2014). Finally, other key features of micronektonic distribution were the much higher NASC values in layers (> 92\% of total NASC values) than in patches, and the almost disappearance of patches $(<$ 481 1\%) at night when compared to the daylight hours (Table 4). The latter feature is related to the diel behaviour of mid-water organisms that disperse at night to feed in the epipelagic zone (Hays, 2003). Moreover, in this work, the potential bias in patches detection linked to the increasing acoustic beam with depth is not considered as well as the depth is not a hindrance to our comparisons. Indeed, $(i)$ in most cases, the absence of patches at night makes the comparison between day and night NASC proportions meaningful and independent of depth and (ii) for the only case of night occurrence of patches (along the Northern track for "fluidlike" organisms), the few detected patches were observed at the same depth as during the day which makes comparison possible regardless of any difference in resolution of detecting patches. The only bias could be an underestimation of deep patches detected during the day. "Fluid-like" scatterers occurred predominantly within layers with a bimodal distribution at shallow and deep depths (Fig. 9). A similar bimodal vertical distribution was previously observed from acoustic-based records at the Polar Front area westward (Pakhomov 
et al., 1994). A prominent feature of “fluid-like" scatter occurrence in Kerguelen waters was a

496 well-defined layer at $\sim 60 \mathrm{~m}$ depth during the day, which likely corresponds to some key crustacean species collected with nets (E. vallentini, Thysanoessa spp., T. gaudichaudii; Pakhomov and Froneman, 1999; Hunt et al., 2011; this study). Noticeably, those crustacean species form the bulk of the food of the most abundant diving air-breathing predator from the area, the macaroni penguin (Eudyptes chrysolophus), which predominantly forages at 20-60 m depth during the day (Sato et al., 2004; Bost and Cherel, unpublished data). Most scatterers of the "gas-bearing" and "undetermined" groups were structured in layers that were more pronounced at night than during the day. Especially obvious was a $\sim 50$ m-deep layer during the northern track that suggests a high abundance of mid-water fish in the upper epipelagic at night. Indeed, surface layers are invaded at that time by myctophids in

506 Kerguelen waters and elsewhere, with the species including a pool of gas-filled swimbladder-, 507 lipid-filled swimbladder- and swimbladderless myctophids (Duhamel et al., 2005; Collins et al., 2012; Saunders et al., 2013). This pattern corresponds well with the night-time diving behaviour of Antarctic fur seals (A. gazella) that prey primarily on mid-water fish at $40-60 \mathrm{~m}$ 510 depth in eastern Kerguelen waters (Lea et al., 2002, 2006). A major characteristic of the "gas511 bearing" group was the significant amount of scatterers structured in patches during daytime. 512 It is likely that patches corresponded to schools of fish, as already depicted in the Atlantic sector of the Southern Ocean (Fielding et al., 2012; Saunders et al., 2013), and that the species

514 were mainly myctophids with a gas-filled swimbladder (Collins et al. 2008). Patch depth 515 observed during the survey was $<180 \mathrm{~m}$, thus suggesting that they were composed of 516 Krefftichthys anderssoni and Protomyctophum spp., and not of deeper-living species as E. carlsbergi (Duhamel et al., 2005; Collins et al., 2008; Flynn and Williams, 2012). Indeed, the survey overlapped the foraging area of the king penguin (Aptenodytes patagonicus) that is 
al., 2002; Charrassin et al., 2004; C.A. Bost and Y. Cherel, unpublished data). Interestingly,

521 patches occurred at different depths during the northern $(\sim 150 \mathrm{~m})$ and southern $(\sim 70 \mathrm{~m})$ tracks, which can be related to different species within patches or to physical oceanography in different water masses or to a combination of both. The limited information available shows that myctophids are linked to the physical, chemical and biological characteristics of the water column, with bottom depth, temperature and oxygen content of the water being key environmental factors controlling their distributions (Hulley and Lutjeharms, 1995). Moreover, despite patches were detected only during daylight, variations in light levels could also affect the vertical distribution of mesopelagic organisms as it has been observed for deep scattering layers (Klevjer et al., 2016).

In conclusion, the present study highlights the usefulness of combining acoustic records with biological sampling to use reliable bi-frequency algorithms to discriminate groups of backscatters. When validated, the method bypasses the problem of net avoidance by micronekton, especially during the daylight hours (Kloser et al., 2009; Pakhomov and

534 Yamamura, 2010; Kaartvedt et al., 2012). Despite uncertainties with species identification and depth limitation in acoustic data, it provides an essential descriptive baseline of the spatial

536 distribution and structure of micronektonic organisms. More at-sea investigations are needed to better define the species-specific acoustic response of crustaceans (e.g. Madureira et al., 1993b), myctophids (e.g. Gautier et al., 2014) and gelatinous organisms (e.g. Wiebe et al., 2010). As it stands, however, the method can already help (i) to link micronektonic group 540 distribution to physical oceanography both horizontally and vertically to better define their 541 oceanic habitats (Koubbi et al., 2011), (ii) to investigate predator-prey interactions by 542 combining real time acoustic surveys and bio-logging (Benoit-Bird et al., 2011; Bedford et 543 al., 2015), and hence (iii) to gather useful information on the functioning of the still poorly 544 known oceanic ecosystem. Overall, the distribution of the acoustic groups fit well with the at- 
545 sea behaviour of air-breathing diving predators from Kerguelen Islands (see above). More

546 specifically, however, a thorough comparison between net trawling and predator foraging 547 ecology underlines some fundamental mismatches that can be investigated using active 548 acoustic surveys. For example, the subantarctic krill E. vallentini is traditionally considered to 549 live deeper than $100 \mathrm{~m}$ during the day (Perissinotto and MacQuaid, 1992; Hamame and 550 Antezana, 2010), while it is one of the most important prey items of various diurnal seabirds 551 (e.g. crested penguins) that feed primarily in the top $50 \mathrm{~m}$ of the water column (Ridoux, 1988; 552 Tremblay and Cherel, 2003; Sato et al., 2004).

\section{Acknowledgements} their assistance during the research cruise LOGIPEV197. This work was supported financially and logistically by the Agence Nationale de La Recherche (ANR MyctO-3D-MAP, Programme Blanc SVSE 7 2011, Y. Cherel), the Institut Polaire Français Paul Emile Victor, and the Terres Australes et Antarctiques Françaises.

\section{References}

Ainley, D.G., DeMaster, D.P., 1990. The upper trophic levels in polar marine ecosystems in: Smith, W.O. (Ed.), Polar Oceanography, Part B. Academic Press, San Diego, pp. 599-630. and annual production of Antarctic krill. Deep-Sea Res. I 56, 727-740.

Bedford, M. Melbourne-Thomas, J., Corney, S., Jarvis, T., Kelly, N., Constable, A., 2015. Prey-field use by a Southern Ocean top predator: enhanced understanding using integrated datasets. Mar. Ecol. Prog. Ser. 526, 169-181. features and micronekton in the Mozambique Channel: an acoustic approach. Deep-Sea Res. II 100, 164173. 
Béhagle, N., Cotté, C., Ryan, T., Gauthier, O., Roudaut, G., Brehmer, P., Josse, E., Cherel, Y., 2016. Acoustic micronektonic distribution structured by macroscale oceanography across $20-50^{\circ} \mathrm{S}$ latitudes in the southwestern Indian Ocean. Deep-Sea Res. I 110, 20-32.

Benoit-Bird, K.J., Au, W.W.L., Wisdom, D.W., 2009. Nocturnal light and lunar cycle effects on diel migration of micronekton. Limnol. Oceanogr. 54, 1789-1800.

Benoit-Bird, K.J., Kuletz, K., Heppell, S., Jones, N., Hoover, B., 2011. Active acoustic examination on the diving behavior of murres foraging on patchy prey. Mar. Ecol. Prog. Ser. 443, 217-235.

Bertrand, A., Grados, D., Habasque, J., Fablet, R., Ballon, M., Castillo, R., Gutierrez, M., Chaigneau, A., Gutierrez, M., Josse, E., Roudaut, G., Lebourges-Dhaussy, A., Brehmer, P., 2013. Routine acoustic data as new tools for a $3 \mathrm{D}$ vision of the abiotic and biotic components of marine ecosystem and their interactions. Acoustics in Underwater Geosciences Symposium (RIO Acoustics), 2013 IEEE/OES, DOI: 10.1109/RIOAcoustics.2013.6683995

Bianchi, D., Stock, C., Galbraith, E.D., Sarmiento, J.L., 2013. Diel vertical migration: ecological controls and impacts on the biological pump in a one-dimensional ocean model. Global Biogeochem. Cycles 27, 478-491.

Blain, S., Renaud, S., Xing, X., Claustre, H., Guinet, C., 2013. Instrumented elephant seals reveal the seasonality in chlorophyll and light-mixing regime in the iron-fertilized Southern Ocean. Geophys. Res. Lett. 40, 6368-6372.

Bocher, P., Cherel, Y., Labat, J.P., Mayzaud, P., Razouls, S., Jouventin, P., 2001. Amphipod-based food web: Themisto gaudichaudii caught in nets and by seabirds in Kerguelen waters, southern Indian Ocean. Mar. Ecol. Prog. Ser. 223, 261-276.

Bost, C., Zorn, T., Le Maho, Y., Duhamel, G., 2002. Feeding of diving predators and diel vertical migration of prey: King penguin's diet versus trawl sampling at Kerguelen Islands Mar. Ecol. Prog. Ser. 227, 51-61.

Brierley, A.S., Ward, P., Watkins, J.L., Goss, C., 1998. Acoustic discrimination of Southern Ocean zooplankton. Deep-Sea Res. II 45, 1155-1173.

Charrassin, J.B., Park, Y.H., Le Maho, Y., Bost, C.A., 2004. Fine resolution 3D temperature fields off Kerguelen from instrumented penguins. Deep-Sea Res. I 51, 2091-2103.

Cherel, Y., Pütz, K., Hobson, K.A., 2002. Summer diet of king penguins (Aptenodytes patagonicus) at the Falkland Islands, southern Atlantic Ocean. Polar Biol. 25, 898-906.

Collins, M.A., Xavier, J.C., Johnston, N.M., North, A.W., Enderlein, P., Tarling, G.A., Waluda, C.M., Hawker, E.J., Cunningham, N.J., 2008. Patterns in the distribution of myctophid fish in the northern Scotia Sea ecosystem. Polar Biol. 31, 837-851.

Collins, M.A., Stowasser, G., Fielding, S., Shreeve, R., Xavier, J.C., Venables, H.J., Enderlein, P., Cherel, Y., Van de Putte, A., 2012. Latitudinal and bathymetric patterns in the distribution and abundance of mesopelagic fish in the Scotia Sea. Deep-Sea Res. II 59-60, 189-198.

Cooper, J, Brown, C.R., 1990. Ornithological research at the sub-Antarctic Prince Edward Islands: a review of achievements. S. Afr. J. Antarct. Res. 20, 40-57.

David, P., Guérin-Ancey, O., Oudot, G., Van Cuyck, J.P., 2001. Acoustic backscattering from salp and target strength estimation. Oceanol. Acta 24, 443-451. 
Demer, D.A., Conti, S.G., 2005. New target-strength model indicates more krill in the Southern Ocean. ICES J. Mar. Sci. 62, 25-32.

De Robertis, A., McKelvey, D.R., Ressler, P.H., 2010. Development and application of an empirical multifrequency method for backscatter classification. Can. J. Fish. Aquat. Sci. 67, 1459-1474.

Domokos, R., 2009. Environmental effects on forage and longline fishery performance for albacore (Thunnus alalunga) in the American Samoa Exclusive Economic Zone. Fish. Oceanogr. 18, 419-438.

Duhamel, G,, Koubbi, P., Ravier, C., 2000. Day and night mesopelagic fish assemblages off the Kerguelen Islands (Southern Ocean). Polar Biol. 23, 106-112.

Duhamel, G., Gasco, N., Davaine, P., 2005. Poissons des îles Kerguelen et Crozet. Guide régional de l'océan Austral. Muséum national d'Histoire naturelle, Paris, France.

Escobar-Flores, P., O’Driscoll, R.L., Montgomery, J.C., 2013. Acoustic characterization of pelagic fish distribution across the South Pacific Ocean. Mar. Ecol. Prog. Ser. 490, 169-183.

Fielding, S., Watkins, J.L., Collins, M.A., Enderlein, P., Venables, H.J., 2012. Acoustic determination of the distribution of fish and krill across the Scotia Sea in spring 2006, summer 2008 and autumn 2009. DeepSea Res II 59, 173-188.

Fielding, S., Watkins, J.L., Trathan, P.N., Enderlein, P., Waluda, C.M., Stowasser, G., Tarling, G.A., Murphy, E.J., 2014. Interannual variability in Antarctic krill (Euphausia superba) density at South Georgia, Southern Ocean: 1997-2013. ICES J. Mar. Sci. 71, 2578-2588.

Flynn, A.J., Williams, A., 2012. Lanternfish (Pisces: Myctophidae) biomass distribution and oceanographictopographic associations at Macquarie Island, Southern Ocean. Mar. Freshwater Res. 63, 251-263.

Foote, K.G., Knudsen, H.P., Vestnes, G., MacLennan, D.N., Simmonds, E.J., 1987. Calibration of acoustic instruments for fish density estimation: a practical guide. ICES Coop. Res. Rep. 144, 1-69.

Godø, O.R., Samuelsen, A., Macaulay, G.J., Patel, R., Hjøllo, S.S., Horne, J., Kaartvedt, S., Johannessen, J.A., 2012. Mesoscale eddies are oases for higher trophic marine life. PLoS ONE 7, e30161.

Greenlaw, C.F., 1977. Backscattering spectra of preserved zooplankton. J. Acoust. Soc. Am. 62, 44-52.

Guinet, C., Cherel, Y., Ridoux, V., Jouventin, P., 1996. Consumption of marine resources by seabirds and seals in Crozet and Kerguelen waters: changes in relation to consumer biomass 1962-85. Antarct. Sci. 8, 23-30.

Hamame, M., Antezana, T., 2010. Vertical diel migration and feeding of Euphausia vallentini within southern Chilean fjords. Deep-Sea Res. II 57, 642-651.

642 Handegard, N.O., du Buisson, L., Brehmer, P., Chalmers, S.J., De Robertis, A., Huse, G., Kloser, R., Macaulay, G., Maury, O., Ressler, P.H., Stenseth, N.C., Godø, O.R., 2013. Towards an acoustic-based coupled observation and modelling system for monitoring and predicting ecosystem dynamics of the open ocean. Fish Fish. 14, 605-615.

Hays, G.C., 2003. A review of the adaptive significanceand ecosystem consequences of zooplankton diet vertical migrations. Hydrobiologia 503, 163-170. frequencies between 0.5 and 3 MHz. J. Acoust. Soc. Am. 67, 135-146. 
Hulley, P.A., Lutjeharms, J.R.E., 1995. The south-western limit for the warm-water, mesopelagic ichthyofauna of the Indo-West-Pacific: lanternfish (Myctophidae) as a case study. S. Afr. J. Mar. Sci., 15, 185-205.

Hunt, B.P.V., Pakhomov, E.A., Williams, R., 2011. Comparative analysis of the 1980s and 2004 macrozooplankton composition and distribution in the vicinity of Kerguelen and Heard Islands: seasonal cycles and oceanographic forcing of long-term change, in: Duhamel, G., Welsford, D. (Eds.) The Kerguelen Plateau: marine ecosystem and fisheries. Société Française d'Ichtyologie, Paris, pp. 79-92.

Irigoien, X., Klevjer, T.A., Røstad, A., Martinez, U., Boyra, G., Acuna, J.L., Bode, A., Echevarria, F., GonzalezGordillo, J.I., Hernandez-Leon, S., Agusti, S., Aksnes, D.L., Duarte, C.M., Kaartvedt, S., 2014. Large mesopelagic fishes biomass and trophic efficiency in the open ocean. Nature Comm. 5, 3271.

Kaartvedt, S., Staby, A., Aksnes, D.L., 2012. Efficient trawl avoidance by mesopelagic fishes causes large underestimation of their biomass. Mar. Ecol. Prog. Ser. 456, 1-6.

Kang, M., Furusawa, M., Miyashita, K., 2002. Effective and accurate use of difference in mean volume backscattering strength to identify fish and plankton. ICES J. Mar. Sci. 59, 794-804.

Klevjer, T. A., Irigoien, X., Røstad, A., Fraile-Nuez, E., Benítez-Barrios, V. M., Kaartvedt,. S., 2016. Large scale patterns in vertical distribution and behaviour of mesopelagic scattering layers. Scientific Reports, 6, 19873.

Koizumi, K., Hiratsuka, S., Saito, H., 2014. Lipid and fatty acids of three edible myctophids, Diaphus watasei, acids. J. Oleo Sci. 63, 461-470.

Kloser, R.J., Ryan, T., Sakov, P., Williams, A., Koslow, J.A., 2002. Species identification in deep water using multiple acoustic frequencies. Can. J. Fish. Aquat. Sci. 59, 1065-1077.

Kloser, R.J., Ryan T.E., Young, J.W., Lewis, M.E., 2009. Acoustic observations of micronekton fish on the scale of an ocean basin: potential and challenges. ICES J. Mar. Sci. 66, 998-1006.

Korneliussen, R.J., Ona, E., 2003. Synthetic echograms generated from the relative frequency response. ICES J. Mar. Sci. 60, 636-640.

Koubbi, P., Moteki, M., Duhamel, G., Goarant, A., Hulley, P.A., O’Driscoll, R., Ishimaru, T., Pruvost, P., Tavernier, E., Hosie, G., 2011. Ecoregionalization of myctophid fish in the Indian sector of the Southern Ocean: results from generalized dissimilarity models. Deep-Sea Res. II 58, 170-180.

Lavery, A.C., Stanton, T.K., McGehee, D.E., Chu, D., 2002. Three-dimensional modeling of acoustic backscattering from fluid-like zooplankton. J. Acoust. Soc. Am. 111, 1197-1210.

Lawson, G.L., Wiebe, P.H., Stanton, T.K., Ashjian, C.J., 2008. Euphausiid distribution along the Western Antarctic Peninsula. Part A: development of robust multi-frequency acoustic techniques to identify euphausiid aggregations and quantify euphausiid size, abundance, and biomass. Deep-Sea Res. II 55, 412431.

Lea, M.A., Cherel, Y., Guinet, C., Nichols, P.D., 2002. Antarctic fur seals foraging in the Polar Frontal Zone: inter-annual shifts in diet as shown from fecal and fatty acid analyses. Mar. Ecol. Prog. Ser. 245, 281-297 [Erratum in Mar. Ecol. Prog. Ser. 253, 310, 2003].

Lea, M.A., Guinet, C., Cherel, Y., Duhamel, G., Dubroca, L., Pruvost, P., Hindell, M., 2006. Impacts of climatic anomalies on provisioning strategies of a Southern Ocean predator. Mar. Ecol. Prog. Ser. 310, 77-94. 
Lebourges-Dhaussy, A., Marchal, E., Menkès, C., Champalbert, G., Biessy, B., 2000. Vinciguerria nimbaria (micronekton), environment and tuna: their relationships in the Eastern Tropical Atlantic. Oceanol. Acta 23, 515-528.

Legendre, P., Fortin, M.J., 2004. Spatial pattern and ecological analysis. Vegetation 80, 107-138.

MacLennan, D.N., Fernandes, P.G., Dalen, J., 2002. A consistent approach to definitions and symbols in fisheries acoustics. ICES J. Mar. Sci. 59, 365-369.

Madureira, L.S.P., Everson, I., Murphy, E.J., 1993a. Interpretation of acoustic data at two frequencies to discriminate between Antarctic krill (Euphausia superba Dana) and other scatterers. J. Plankton Res. 15, 787-802.

Madureira, L.S.P., Ward, P., Atkinson, A., 1993b. Differences in backscattering strength determined at 120 and $38 \mathrm{kHz}$ for three species of Antarctic macroplankton. Mar. Ecol. Prog. Ser. 93, 17-24.

Margalef, R., 1979. The organization of space. Oikos 33, 152-159.

Marshall, N.B., 1960. Swimbladder structure of deep-sea fishes in relation to their systematics and biology. Discovery Rep. XXXI, 1-122.

MATLAB 7.11.0.584, Release 2010b, The MathWorks, Inc., Natick, Massachusetts, United States.

Meillat, M., 2012. Essais du chalut mésopélagos pour le programme MYCTO 3D - MAP de l'IRD, à bord du Marion Dufresne (du 10 au 21 août 2012). Rapport de mission, Ifremer.

Miller, D.G.M., 1982. Results of a combined hydroacoustic and midwater trawling survey of the Prince Edward Island group. S. Afr. J. Antarct. Res. 12, 3-22.

Nicol, S., Foster, J., Kawaguchi, S., 2012. The fishery for Antarctic krill - recent developments. Fish Fish. 13, $30-40$.

Pakhomov, E.A., Perissinotto, R., McQuaid, C.D., 1994. Comparative structure of the macrozooplankton/micronekton communities of the Subtropical and Antarctic Polar Fronts. Mar. Ecol. Prog. Ser. 111, 155-169.

Pakhomov, E.A., Perissinotto, R., McQuaid, C.D., 1996. Prey composition and daily rations of myctophid fishes in the Southern Ocean. Mar. Ecol. Prog. Ser. 134, 1-14.

Pakhomov, E.A., Froneman, P.W., 1999. Macroplankton/micronekton dynamics in the vicinity of the Prince Edward Islands (Southern Ocean). Mar. Biol. 134, 501-515.

Pakhomov, E.A., Froneman, P.W., 2000. Composition and spatial variability of macroplankton and micronekton within the Antarctic Polar Frontal Zone of the Indian Ocean during austral autumn 1997. Polar Biol. 23, 410-419.

Pakhomov, E., Yamamura, O., 2010. Report of the advisory panel on micronekton sampling inter-calibration experiment. PICES Scient. Rep. 38, 1-108.

Pauly, D., Christensen, V., Dalsgaard, J., Froese, R., Torres Jr, F., 1998. Fishing down marine food webs. Science $279,860-863$.

Perissinotto, R., McQuaid, C.D., 1992. Land-based predator impact on vertically migrating zooplankton and micronekton advected to a Southern Ocean archipelago. Mar. Ecol. Prog. Ser. 80, 15-27.

Potier, M., Marsac, F., Cherel, Y., Lucas, V., Sabatié, R., Maury, O., Ménard, F., 2007. Forage fauna in the diet of three large pelagic fishes (lancetfish, swordfish and yellowfin tuna) in the western equatorial Indian Ocean. Fish. Res. 83, 60-72. 
R Core Team, 2014. R: a language and environment for statistical computing. R Foundation for Statistical Computing, Vienna, Austria. URL http://www.R-project.org/.

Ressler, P.H., Dalpadado, P., Macaulay, G.J., Handegard, N., Skern-Mauritzen, M., 2015. Acoustic surveys of euphausiids and models of baleen whale distribution in the Barents Sea. Mar. Ecol. Prog. Ser. 527, 13-29.

Ridoux, V., 1988. Subantarctic krill, Euphausia vallentini Stebbing, preyed upon by penguins around Crozet Islands (Southern Indian Ocean): population structure and annual cycle. J. Plankton Res. 10, 675-690.

Robertson, K.M., Chivers, S.J., 1997. Prey occurrence in pantropical spotted dolphins, Stenella attenuata, from the eastern tropical Pacific. Fish. Bull., 95, 334-348.

Rodhouse, P.G., Nigmatullin, C.M., 1996. Role as consumers. Phil. Trans. R. Soc. Lond. 351, 1003-1022.

Rodhouse, P.G., White, M.G., 1995. Cephalopods occupy the ecological niche of epipelagic fish in the Antarctic Polar Frontal Zone. Biol. Bull. 189, 77-80.

Sato, K., Charrassin, J.B., Bost, C.A., Naito, Y., 2004. Why do macaroni penguins choose shallow body angles that result in longer descent and ascent durations? J. Exp. Biol. 207, 4057-4065.

Saunders, R.A., Fielding, S., Thorpe, S.E., Tarling, G.A., 2013. School characteristics of mesopelagic fish at South Georgia. Deep Sea Res. I 81, 62-77.

Shaviklo, A.R., Rafipour, F., 2013. Surimi and surimi seafood from whole ungutted myctophid mince. LWTFood Sci. Technol. 54, 463-468.

Simmonds, E.J., MacLennan, D.N., 2005. Fisheries acoustics: theory and practice. Second ed., Wiley-Blackwell, Oxford, UK.

Spear, L.B., Ainley, D.G., Walker, W.A., 2007. Foraging dynamics of seabirds in the eastern tropical Pacific Ocean. Studies Avian Biol. 35, 1-99.

Stanton, T.K., Wiebe, P.H., Chu, D., Benfield, M.C., Scanlon, L., Martin, L., Eastwood, R.L., 1994. On acoustic estimates of zooplankton biomass. ICES J. Mar. Sci. 51, 505-512.

Stanton, T.K., Chu, D., Wiebe, P.H., Martin, L., Eastwood, R.L., 1998a. Sound scattering by several zooplankton groups. I. Experimental determination of dominant scattering mechanisms. J. Acoust. Soc. Am. 103, 225-235.

Stanton, T.K., Chu, D., Wiebe, P.H., 1998b. Sound scattering by several zooplankton groups. II. Scattering models. J. Acoust. Soc. Am. 103, 236-254.

Stanton, T.K., Chu, D., 2000. Review and recommendations for the modelling of acoustic scattering by fluid-like elongated zooplankton: euphausiids and copepods. ICES J. Mar. Sci. 57, 793-807.

Sund, O., 1935. Echo sounding in fishery research. Nature 135, 953.

Tremblay, Y., Cherel, Y., 2003. Geographic variation in the foraging behaviour, diet and chick growth of rockhopper penguins. Mar. Ecol. Prog. Ser. 251, 279-297.

Warren, J.D., Stanton, T.K., Benfield, M.C., Wiebe, P.H., Chu, D., Sutor, M., 2001. In situ measurements of acoustic target strengths of gas-bearing siphonophores. ICES J. Mar. Sci. 58, 740-749.

Wiebe, P.H., Chu, D., Kaartvedt, S., Hundt, A., Melle, W., Ona, E., Batta-Lona, P., 2010. The acoustic properties of Salpa thompsoni. ICES J. Mar. Sci. 67, 583-593.

Williams, A., and Koslow, J.A. 1997. Species composition, biomass and vertical distribution of micronekton over the mid-slope region off southern Tasmania. Mar. Biol. 130, 259-276. 
768 Woehler, E.J., Green, K., 1992. Consumption of marine resources by seabirds and seals at Heard Island and the 769 McDonald Islands. Polar Biol.12, 659-665.

770 Ye, Z., 1997. Low-frequency acoustic scattering by gas-filled prolate spheroids in liquids. J. Acoust. Soc. Am. 771 101, 1945-1952.

772

773

774

775 
Fig. 1. 38 and $120 \mathrm{kHz}$ echograms representing acoustic density (in color, $\mathrm{S}_{\mathrm{v}}$ in $\mathrm{dB}$ ) recorded on the 24th of January 2014 morning from 30 to 300m depth in east waters off Kerguelen.

778

Fig. 2. Schematic description of the relative frequency response, $r(f)$. Horizontal lines indicate typical range positions of selected acoustic categories when measured at frequencies 18-200 kHz. Source: Korneliussen and Ona (2003).

782

Fig. 3. Acoustic records and the corresponding cruise trawls (T07 and T14) that were used to define thresholds of difference in the bi-frequency algorithm. Upper panel: complete trawl echograms with trawling depths (continuous black line) and limits of data extraction (dashed black lines). Lower panel: extracted echogram samples focusing on the trawl targeted aggregates that were selected from acoustic identification estimation. Left: T07 trawl (euphausiids) sampling on the $120 \mathrm{kHz}$ frequency to discriminate the "fluid-like" group. Right: T14 trawl (gas-filled swimbladder fish) on the $38 \mathrm{kHz}$ frequency to discriminate the "gas-bearing” group.

Fig. 4. Left panel (a): frequency response of each sample considered relatively to the $38 \mathrm{kHz}$ frequency, with "fluid-like" samples (from the trawl T07) represented in red and "gasbearing" samples (from the trawl T14) in blue. Right panel (b): bar chart of the percentage of "fluid-like" (in red) and "gas-bearing" (in blue) total NASC, according to a -15 to $25 \mathrm{~dB}$ range of threshold of difference, used to define the best thresholds $(-1$ and $+2 \mathrm{~dB})$ delimiting the

797 "undetermined" group by transferring a maximum of 10\% of their acoustic energy (total 798 NASC).

800 Fig. 5. Summary diagram of the bi-frequency algorithm method used in this study. 
802 Fig. 6. Representative diagram of the number of patches (in blue) and its derivative (in green)

803 detected along increasing $S_{\mathrm{v}}$ values from -70 to $-40 \mathrm{~dB}$. The value of $-63 \mathrm{~dB}$ corresponds to a

804 threshold level over which the number of patches did not further increased.

805

806 Fig. 7. 38 and $120 \mathrm{kHz}$ echograms representing acoustic density (in color, $\mathrm{S}_{\mathrm{v}}$ in $\mathrm{dB}$ ) recorded 807 on the 24th of January 2014 morning from 30 to 300m depth in east waters off Kerguelen for 808 (a) patches- and (b) layers structures.

809 Fig. 8. Total density (NASC, in $\mathrm{m}^{2} \cdot \mathrm{nmi}^{-2}$, colored on ship track) integrated from 30 to $300 \mathrm{~m}$

810 depth for each acoustic group ("gas-bearing", fluid-like" and "undetermined" groups) and for

811 each type of structures (patches and layers).

812

813 Fig. 9. Mean vertical NASC profiles from 30 to $300 \mathrm{~m}$ depth of each acoustic group ("gas-

814 bearing", fluid-like" and "undetermined" groups) for day (black lines) and night (grey lines)

815 and for each type of structures (patches and layers). Dashed lines indicate the $95 \%$ confidence 816 intervals. 